\title{
A Reorganized GABAergic Circuit in a Model of Epilepsy: Evidence from Optogenetic Labeling and Stimulation of Somatostatin Interneurons
}

\author{
Zechun Peng, ${ }^{1}$ Nianhui Zhang, ${ }^{1}$ Weizheng Wei, ${ }^{2}$ Christine S. Huang, ${ }^{1}$ Yliana Cetina, ${ }^{1}$ Thomas S. Otis, ${ }^{1,3}$ \\ and Carolyn R. Houser ${ }^{1,3}$ \\ ${ }^{1}$ Departments of Neurobiology and ${ }^{2}$ Neurology, ${ }^{3}$ Brain Research Institute, David Geffen School of Medicine at the University of California, Los Angeles, Los \\ Angeles, California 90095, and ${ }^{4}$ Research Service, Veterans Administration Greater Los Angeles Healthcare System, West Los Angeles, Los Angeles, \\ California 90073
}

\begin{abstract}
Axonal sprouting of excitatory neurons is frequently observed in temporal lobe epilepsy, but the extent to which inhibitory interneurons undergo similar axonal reorganization remains unclear. The goal of this study was to determine whether somatostatin (SOM)-expressing neurons in stratum (s.) oriens of the hippocampus exhibit axonal sprouting beyond their normal territory and innervate granule cells of the dentate gyrus in a pilocarpine model of epilepsy. To obtain selective labeling of SOM-expressing neurons in s. oriens, a Cre recombinase-dependent construct for channelrhodopsin2 fused to enhanced yellow fluorescent protein (ChR2-eYFP) was virally delivered to this region in SOM-Cre mice. In control mice, labeled axons were restricted primarily to s. lacunosum-moleculare. However, in pilocarpine-treated animals, a rich plexus of ChR2-eYFP-labeled fibers and boutons extended into the dentate molecular layer. Electron microscopy with immunogold labeling demonstrated labeled axon terminals that formed symmetric synapses on dendritic profiles in this region, consistent with innervation of granule cells. Patterned illumination of ChR2-labeled fibers in s. lacunosum-moleculare of CA1 and the dentate molecular layer elicited GABAergic inhibitory responses in dentate granule cells in pilocarpine-treated mice but not in controls. Similar optical stimulation in the dentate hilus evoked no significant responses in granule cells of either group of mice. These findings indicate that under pathological conditions, SOM/GABAergic neurons can undergo substantial axonal reorganization beyond their normal territory and establish aberrant synaptic connections. Such reorganized circuitry could contribute to functional deficits in inhibition in epilepsy, despite the presence of numerous GABAergic terminals in the region.
\end{abstract}

\section{Introduction}

Axonal reorganization of remaining excitatory neurons is a frequently observed morphological change in lesion-induced epilepsy and can be extensive. Mossy fiber sprouting of dentate granule cells provides one of the clearest examples of such changes (Tauck and Nadler, 1985; Sutula et al., 1989; Houser et al., 1990; Babb et al., 1991; Buckmaster and Dudek, 1997), but axonal reorganization of other excitatory neurons, including hippocampal pyramidal cells, also occurs (Meier and Dudek, 1996; Perez et al., 1996; Esclapez et al., 1999; Smith and Dudek, 2001).

\footnotetext{
Received May 13, 2013; revised July 29, 2013; accepted Aug. 1, 2013.

Author contributions: Z.P., N.Z., W.W., T.S.O., and C.R.H. designed research; Z.P., N.Z., W.W., C.S.H., and Y.C. performed research; Z.P., N.Z., W.W., T.S.O., and C.R.H. analyzed data; T.S.O. and C.R.H. wrote the paper.

This work was supported by National Institutes of Health Grants NS075245 (C.R.H.), RRO29267 (T.S.0.), and NS068408 (T.S.O.) and Veterans Affairs Medical Research Funds (C.R.H.). We gratefully acknowledge Dr. Karl Deisseroth for making reagents available through Addgene and the Penn Vector Core in the School of Medicine Gene Therapy Program at the University of Pennsylvania for preparation of the viral vector. We thank Dr. Istvan Mody for helpful discussions.

The authors declare no competing financial interests.

Correspondence should be addressed to Dr. Carolyn R. Houser, Department of Neurobiology, CHS 73-235, David Geffen School of Medicine at UCLA, 10833 Le Conte Avenue, Los Angeles, CA 90095-1763. E-mail: houser@mednet.ucla.edu.

DOI:10.1523/JNEUROSCI.2045-13.2013

Copyright $\odot 2013$ the authors $\quad 0270-6474 / 13 / 3314392-14 \$ 15.00 / 0$
}

Whether inhibitory neurons exhibit similar axonal growth and synaptogenesis has remained less clear. Although sprouting of GABA neurons has been suggested as an explanation for the persistence or increase in labeling of GABAergic axons and terminals in human temporal lobe epilepsy and related animal models (Davenport et al., 1990; Mathern et al., 1995; Bausch, 2005; Zhang et al., 2009; Thind et al., 2010), evidence has come primarily from immunohistochemical studies. Thus it remains possible that such labeling results from increased expression of GABA or related markers in remaining neurons (Cavalheiro et al., 1994; Houser and Esclapez, 1996; Esclapez and Houser, 1999; Bausch, 2005; Boulland et al., 2007), rather than actual growth and reorganization of GABAergic axons.

Buckmaster et al. (2011) have recently provided support for sprouting of somatostatin (SOM)-containing neurons in the hilus that were labeled endogenously for green fluorescent protein (GFP) in a mouse model of epilepsy (Zhang et al., 2009). Despite a significant loss of hilar SOM neurons, some labeled neurons remained, and an increase in the length of their axons was found, along with an increase in innervation of the granule cells by remaining hilar SOM neurons. These findings strongly support compensatory sprouting of remaining SOM/GABA neurons to replace the efferents of vulnerable hilar neurons of the same type. 
Such local sprouting of GABA neurons, although suggested previously, has been difficult to demonstrate.

This type of axonal reorganization differs from that of some glutamatergic excitatory neurons in which reorganized fibers occupy new territories and create altered circuitry. Mossy fibers of dentate granule cells change their trajectory and innervate proximal regions of granule cells in the inner molecular layer of the dentate gyrus that were originally innervated by excitatory hilar mossy cells (Jiao and Nadler, 2007). Thus the reorganized mossy fibers occupy sites that are distinctly different from their normal terminations, creating an aberrant circuit. It is not known whether inhibitory interneurons also exhibit such extensive axonal growth into regions they normally do not occupy and thus could form similarly altered circuits.

To address this question, we used SOM-Cre recombinase (SOM-Cre) mice, in conjunction with viral delivery of a Credependent channelrhodopsin2-enhanced yellow fluorescent protein (ChR2-eYFP) construct, to label remaining SOM neurons in stratum (s.) oriens of CA1 in a mouse model of epilepsy and identify the location of their axonal plexus. Patterned illumination allowed us to stimulate ChR2-positive axon terminals and determine their function. Preliminary reports of some findings have been presented previously (Houser et al., 2004; Peng et al., 2013).

\section{Materials and Methods}

Overview. An initial time course study was conducted in C57BL/6 mice to determine the progression of changes in SOM neurons and their axonal plexus in the hippocampal formation following pilocarpine-induced status epilepticus. The findings provided the basis for further study of possible axonal reorganization of SOM neurons in this epilepsy model, using a SOM-Cre mouse to obtain cell type-specific expression and viral delivery of a Cre-dependent ChR2-eYFP construct to obtain regional selectivity. These latter experiments allowed both morphological and electrophysiological analyses of SOM neurons and their reorganized processes in a mouse model of epilepsy during the chronic period.

Animals. For the initial time course study, C57BL/6 male mice (Harlan), 6-8 weeks of age at the time of treatment, were studied at the following intervals following pilocarpine-induced status epilepticus: $24 \mathrm{~h}, 4 \mathrm{~d}$, 1 week, 2 weeks, 1 month, and 2-3 months. Three to eight pilocarpine-treated and at least two age-matched control mice were included at each time point.

In the second set of studies, transgenic mice that express Cre under the control of the SOM promoter (SOM-Cre mice) were used to characterize the axonal plexus of SOM neurons that have their cell bodies in s. oriens in normal and control $(n=15)$ and pilocarpine-treated $(n=9)$ mice following viral delivery of a Cre-dependent ChR2-eYFP construct to s. oriens of CA1. Animals for breeding were generously provided by Z. Josh Huang and Sandra Kuhlman (Cold Spring Harbor Laboratory and University of California at Los Angeles), and the SOM-Cre mice (also referred to as Sst-Cre), on a C57BL/6 background, are now commercially available (Stock \#013044; The Jackson Laboratory). The SOM-Cre mice were also bred to Ai9 reporter mice that express the red fluorescent protein (RFP) variant tdTomato following Cre-mediated recombination (Stock \#007909; The Jackson Laboratory). The generated SOM-Cre-Ai9 mice, $\sim 8$ weeks of age $(n=4)$, were used to determine the selectivity and specificity of Cre expression in SOM neurons in the hippocampal formation of the SOM-Cre transgenic mice. All animal-use protocols conformed to the National Institutes of Health guidelines and were approved by the University of California, Los Angeles, Chancellor's Animal Research Committee.

Mouse pilocarpine treatment. The pilocarpine mouse model of recurrent seizures has been described in detail in previous studies (Peng and Houser, 2005; Houser et al., 2008). Morphological characteristics of this model of epilepsy in C57BL/6 mice include a lack of extensive extrahippocampal damage in the majority of animals and a consistent loss of hilar neurons, including SOM-expressing neurons, in the dentate gyrus. Importantly, spontaneous seizures develop over time in a high percentage of these mice, as determined by video monitoring in our laboratory. In a previous group of pilocarpine-treated mice $(n=38)$ that were monitored $24 \mathrm{~h}$ per day for at least $7 \mathrm{~d}$, behavioral seizures were observed in $97.4 \%$ of the mice.

In the current study, both young adult ( $6-8$ weeks) male C57BL/ 6 and SOM-Cre mice (C57BL/6 background) were used, and sustained seizures were induced in experimental animals by the administration of pilocarpine, a muscarinic cholinergic agonist. Mice were initially injected with scopolamine methyl nitrate ( $1 \mathrm{mg} / \mathrm{kg}$, s.c.; Sigma-Aldrich) to reduce peripheral cholinergic effects. Thirty minutes later, experimental animals in each group received an injection of pilocarpine hydrochloride (300$340 \mathrm{mg} / \mathrm{kg}$, s.c.; Sigma-Aldrich) to induce status epilepticus. At $2 \mathrm{~h}$ after the onset of sustained seizures, diazepam $(7.5 \mathrm{mg} / \mathrm{kg}$, s.c.; Hospira) was administered to ameliorate or reduce behavioral seizures. Additional diazepam injections $(5 \mathrm{mg} / \mathrm{kg})$ were given if seizures were not reduced sufficiently or recurred within $1 \mathrm{~h}$ after the first diazepam injection. Control animals received an identical series of injections except that pilocarpine was replaced with a similar volume of sterile saline. Following the induced seizure episode, pilocarpine-treated animals recovered, generally resumed eating and drinking by the following day, and displayed normal behavior over the next few days. Within 1-2 weeks, the animals developed brief, spontaneous behavioral seizures, generally lasting $60 \mathrm{~s}$ or less, as determined by video monitoring.

Viral vector injections. To selectively label SOM neurons in s. oriens of CA1, SOM-Cre male mice were injected with a Cre-dependent doublefloxed recombinant adeno-associated viral $(\mathrm{AAV})$ vector containing constructs encoding ChR2-eYFP. The mice were $\sim 12$ weeks of age at the time of injection and thus 5 weeks following pilocarpine or control injections. Slightly younger mice (8-10 weeks of age) were used for viral injections in normal SOM-Cre animals. The viral vector, AAV2/ 9.EF1a.DIO.hChR2(H134R)-EYFP.WPRE.hGH (Addgene plasmid \#20298), was kindly made available by Karl Deisseroth and produced by the Penn Vector Core in the School of Medicine Gene Therapy Program at the University of Pennsylvania (Zhang et al., 2010). Mice were anesthetized with isoflurane, and the viral vector was stereotaxically injected in the dorsal hippocampus with a Nanoject II injector (Drummond Scientific), using glass pipettes. In the majority of animals, the injection was made at a single site, and the pipette tip was positioned at the dorsal surface of s. oriens of CA1 (2.2 mm posterior, $1.4 \mathrm{~mm}$ lateral, and $1.3 \mathrm{~mm}$ ventral to bregma) (Paxinos and Franklin, 2001). A small animal stereotaxic instrument with digital display console (Model 940; Kopf Instruments) was used for precise positioning of the pipette, to label Cre-expressing SOM neurons in s. oriens without labeling SOM neurons located deeper in the dentate gyrus. Injections (23 nl per injection; 1-2 injections at each site) were made unilaterally in animals used for neuroanatomical study $(n=16 ; 11$ normal or control mice and 5 pilocarpine-treated mice) and bilaterally in all but one animal used for electrophysiology $(n=8$; 4 normal or control and 4 pilocarpine-treated). Following the injection, the pipette was left in position for 5-10 min before it was slowly retracted from the brain.

For these studies, all pilocarpine-treated SOM-Cre mice had exhibited at least $2 \mathrm{~h}$ of sustained behavioral seizures (status epilepticus). Control mice included those that received the same treatment as the pilocarpine mice except for replacement of pilocarpine with saline, as well as mice that received pilocarpine injections but failed to develop status epilepticus ( 2 of 11 pilocarpine-injected mice). Current and previous studies of such mice in our lab have shown that these mice do not develop spontaneous seizures or exhibit seizure-induced patterns of cell loss or other morphological changes. Thus they serve as ideal controls for the effects of status epilepticus and were included in the control group for the neuroanatomical studies.

Tissue preparation for light microscopy. All mice used for neuroanatomical studies were deeply anesthetized with sodium pentobarbital ( 90 $\mathrm{mg} / \mathrm{kg}$, i.p.) and perfused transcardially with $4 \%$ paraformaldehyde in $0.12 \mathrm{M}$ phosphate buffer (PB), $\mathrm{pH} 7.3$. After $1 \mathrm{~h}$ at $4^{\circ} \mathrm{C}$, brains were removed and postfixed for $1 \mathrm{~h}$. After rinsing, brains were cryoprotected in a $30 \%$ sucrose solution overnight at $4^{\circ} \mathrm{C}$, embedded in OCT com- 
pound (Sakura Finetek), frozen on dry ice, and sectioned at $30 \mu \mathrm{m}$ with a cryostat (CM 3050S; Leica Microsystems). Brains used in the time course study of SOM labeling were sectioned coronally through the rostral (septal) half and then horizontally through the caudal (temporal) half of the hippocampal formation. Brains studied following viral vector injections were sectioned coronally throughout the hippocampus.

Antibodies. Rabbit polyclonal antiserum to somatostatin-14 (Cat. No. T-4103; Peninsula Laboratories) was used for all immunohistochemical studies of SOM localization. Specificity of the antiserum for SOM immunohistochemistry has been demonstrated previously (Ma et al., 2006). Rabbit antiserum to GFP (Cat. No. AB3080; Millipore Bioscience Research Reagents) was used to localize eYFP in electron microscopic studies following viral-mediated expression of ChR2-eYFP.

Immunohistochemistry for light microscopy. For time course and cell count studies, SOM was localized with standard avidin-biotin peroxidase immunohistochemical methods. Free-floating sections were incubated in $1 \% \mathrm{H}_{2} \mathrm{O}_{2}$ for $30 \mathrm{~min}$ to reduce endogenous peroxidase-like activity. After rinsing in $0.1 \mathrm{~m}$ Tris buffered saline (TBS; $\mathrm{pH} 7.3$ ), sections were incubated in 10\% normal goat serum diluted in TBS containing $1 \%$ Triton X-100 for 2-3 h to reduce nonspecific binding and increase penetration of the antibodies. Thorough rinses were performed between all subsequent steps in the immunohistochemical procedures. Sections were incubated in primary SOM antisera $(1: 25,000)$ for $72 \mathrm{~h}$ at room temperature, incubated in biotinylated secondary antiserum (goat anti-rabbit IgG, 1:200; Vector Laboratories) at room temperature for $1 \mathrm{~h}$, and then incubated in avidin-biotin peroxidase complex (1:100; Vectastain Elite ABC kit; Vector Laboratories) for $1 \mathrm{~h}$. For the time course studies, nickel intensification of diaminobenzidine (DAB) was used to enhance axon terminal labeling. To visualize the peroxidase labeling for studies of cell counts, sections were processed with Stable DAB (Invitrogen) for $12 \mathrm{~min}$, and immunolabeling was enhanced by incubation in $0.003 \%$ osmium tetroxide in PBS for 30 s. Sections were mounted on slides, dehydrated, and coverslipped.

Double-immunofluorescence labeling. For double-labeling studies, SOM was localized with immunofluorescence methods in sections expressing endogenous fluorescence labeling of either RFP, a reporter of Cre localization in SOM-Cre-Ai9 mice, or eYFP, an indicator of ChR2eYFP expression in SOM-Cre mice following viral injections. For both sets of studies, sections were incubated for $2 \mathrm{~h}$ in $10 \%$ normal goat serum to block nonspecific binding sites and $0.3 \%$ Triton X-100 to increase reagent penetration. Sections for SOM and RFP localization were incubated in SOM antisera (1:5000) for 1 week to maximize penetration of the immunohistochemical reagents, incubated in goat anti-rabbit IgG conjugated to Alexa Fluor 488 (Invitrogen) at room temperature for $4 \mathrm{~h}$; and mounted on slides, and coverslipped with antifade medium ProLong Gold (Invitrogen). Similar methods were used for colocalizing SOM in eYFP-labeled cells, except that the incubation in SOM antisera (1:5000) was for $48 \mathrm{~h}$, and the sections were incubated in goat anti-rabbit IgG conjugated to Alexa Fluor 555 (Invitrogen) at room temperature for $4 \mathrm{~h}$.

Tissue preparation for electron microscopy. Pilocarpine-treated mice $(8$ weeks after status epilepticus and 3 weeks after AAV-mediated transfection of ChR2-eYFP) were perfused as described for light microscopy except that $0.1 \%$ glutaraldehyde was added to the $4 \%$ paraformaldehyde fixative solution. After perfusion, brains remained in situ for $2 \mathrm{~h}$ at $4^{\circ} \mathrm{C}$ and were then removed and postfixed in 2\% paraformaldehyde and $2.5 \%$ glutaraldehyde in $\mathrm{PB}$ overnight at $4^{\circ} \mathrm{C}$. After rinsing, coronal sections of the forebrain that included the hippocampus were cut at $60 \mu \mathrm{m}$ on a vibratome (VT1000S; Leica Microsystems).

Pre-embedding immunogold labeling for electron microscopy. Sections were pretreated with $1 \%$ sodium borohydride in PB for $30 \mathrm{~min}$ and incubated in 10\% normal goat serum in TBS for $2 \mathrm{~h}$ and then in primary rabbit antiserum to GFP (diluted 1:100) in $0.1 \mathrm{~m}$ TBS containing $2 \%$ normal goat serum for $4-6 \mathrm{~h}$ at room temperature followed by $48 \mathrm{~h}$ at $4^{\circ} \mathrm{C}$. Sections were incubated in secondary antiserum, goat anti-rabbit IgG, conjugated to $1.4 \mathrm{~nm}$ colloidal gold particles (1:80; Cat. No. 2004; Nanoprobes) in TBS with 2\% normal goat serum for $4 \mathrm{~h}$ at room temperature. After thorough rinsing with TBS and then double-distilled water, sections were processed for $12.5 \mathrm{~min}$ in a gold-enhancement solution (Cat. No. 2113; Nanoprobes) prepared according to manufacturer's pro- tocol, as described previously (Wyeth et al., 2010). Immunolabeling controls included omission of either GFP antiserum or colloidal gold-labeled secondary antiserum. No specific immunogold labeling was found in these sections.

Before embedding for electron microscopy, sections were postfixed for $1 \mathrm{~h}$ in $2 \%$ paraformaldehyde and $2.5 \%$ glutaraldehyde, rinsed in $\mathrm{PB}$, and processed for flat embedding as described previously (Zhang and Houser, 1999). Briefly, sections were treated with $1 \%$ osmium tetroxide in PB for $1 \mathrm{~h}$, dehydrated with graded ethanol, and incubated with Durcupan resin overnight at room temperature. Sections were flat embedded with Durcupan resin and polymerized at $56^{\circ} \mathrm{C}$ for $24 \mathrm{~h}$. Regions containing $\mathrm{CA} 1$ and the dentate gyrus were trimmed out of the sections, reembedded on capsules filled with polymerized Durcupan resin, and polymerized at $56^{\circ} \mathrm{C}$ for an additional $24 \mathrm{~h}$. Ultrathin sections $(60-70$ $\mathrm{nm}$ ) were cut with an ultramicrotome (Reichert-Jung), and picked up on nickel mesh grids that were freshly coated with a Coat-Quick G pen (Electron Microscopy Sciences). Sections were then rinsed thoroughly and counterstained with a saturated solution of uranyl acetate for $40 \mathrm{~min}$ and lead citrate for $4 \mathrm{~min}$. The sections were studied and photographed with a JEOL 100CX II electron microscope at 19,000×.

Analysis of morphological data. Sections with single labeling of SOM for the time course study were analyzed qualitatively, and digital images were obtained with a Zeiss Axioskop 2 microscope equipped with an AxioCam digital camera system and AxioVision 4.8 software. Fluorescence-labeled sections were scanned with an LSM 510 META or LSM 710 (Carl Zeiss) confocal microscope, and confocal images were analyzed with LSM 5 Image Examiner and Zen 2011 imaging software (Carl Zeiss).

To determine the extent of SOM cell loss in the hilus and s. oriens in the pilocarpine-treated animals, coronal sections from the dorsal hippocampal formation of normal $(n=4)$ and pilocarpine-treated $(n=4)$ mice were processed for SOM immunohistochemistry in the same run. Cell counts were made in two coronal sections (300-400 $\mu \mathrm{m}$ apart) in the same animals used for morphological analysis of axonal sprouting, contralateral to the side of the AAV injection but at comparable levels to the injection and thus from the rostral hippocampal formation. SOMlabeled cells were mapped, using an Axio Imager Z1 microscope (Carl Zeiss) equipped with a StereoInvestigator system (MBF Bioscience). Borders of the hilus and s. oriens of CA1 were outlined, and all SOMlabeled cells with a defined nucleus and proximal segments of dendrites were plotted and counted within each region $(20 \times$ objective). Data were analyzed with Student's $t$ test, and significance levels were established as $p<0.05$.

To determine the selectivity and specificity of RFP labeling (used as a reporter of Cre-expression) for SOM neurons, the extent of colocalization of these markers was analyzed in CA1 of the dorsal hippocampus in SOM-Cre-Ai9 mice ( $n=4)$ with an LSM 710 (Carl Zeiss) confocal microscope. $Z$-stack images (10-16 slices, $1 \mu \mathrm{m}$ optical thickness; $20 \times$ objective) were acquired in contiguous regions of the hippocampal formation, using the Tile Scan program (Zen 2011; Carl Zeiss). Optical slices were scanned separately for each label, alternating between the two channels (excitation spectra of 488 and $543 \mathrm{~nm}$ ), in each section throughout the $Z$-stack. Projection images of each region were assembled into a montage of the hippocampal formation. Regions of CA1 (s. oriens/alveus, s. pyramidale, s. radiatum, and s. lacunosum-moleculare) were delineated, and all single- and double-labeled cells were mapped and counted $(2$ sections per animal $\times 2$ sides $=16$ hippocampal images $)$. Labeling for both RFP (endogenous) and SOM (immunohistochemical) extended throughout the thickness of the section. Percentages of both RFP and SOM neurons that were double labeled for the other marker were calculated for each region of CA1. Labeling patterns in other regions of the hippocampal formation were analyzed qualitatively.

To confirm that viral-mediated expression of ChR2-eYFP was localized to SOM neurons, double-labeled sections were analyzed as described for eYFP and SOM labeling. After initial studies confirmed that virtually all eYFP-labeled neurons were doubled labeled for SOM, no further quantitative analysis of double labeling was conducted. For detailed analysis of eYFP expression in cell bodies and axons following AAV injections, confocal $Z$-stack images ( $\sim 16$ slices, $1 \mu \mathrm{m}$ optical thickness) were 

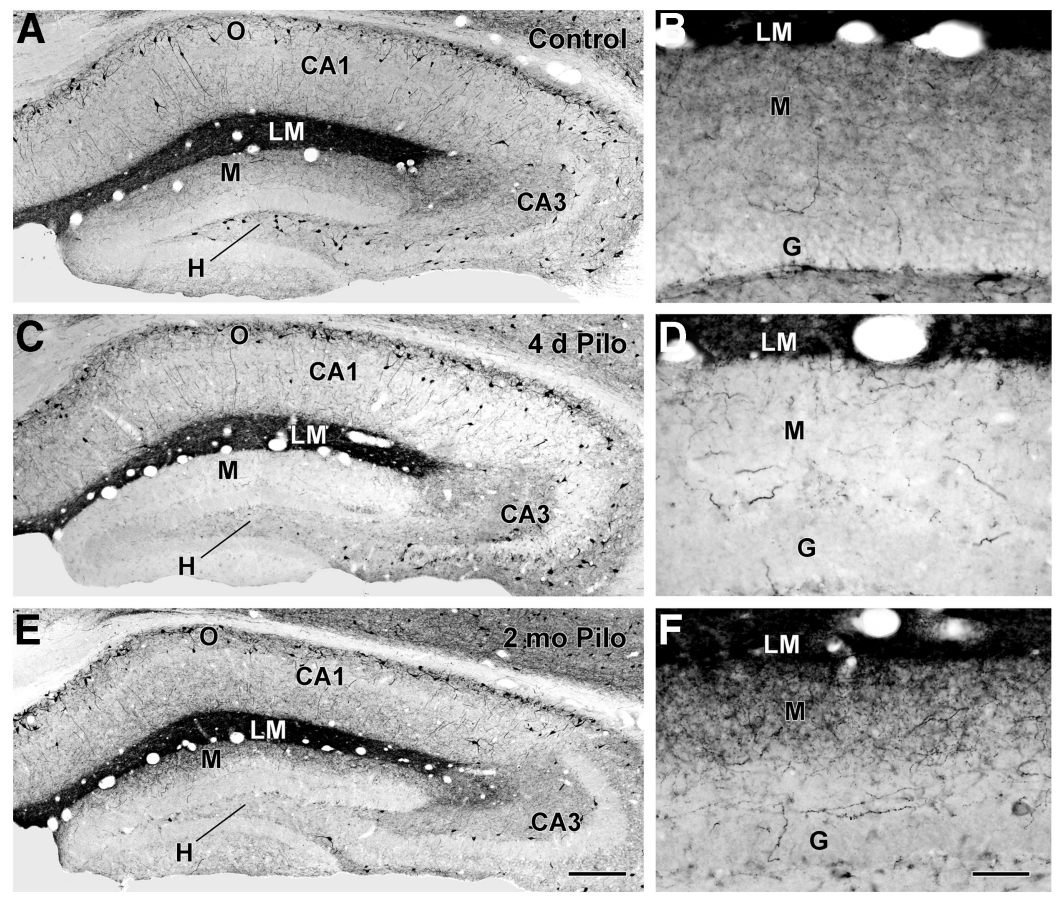

Figure 1. SOM immunoreactivity in control $(\boldsymbol{A}-\boldsymbol{B})$ and pilocarpine (Pilo)-treated $(\boldsymbol{C}-\boldsymbol{F})$ mice. $\boldsymbol{A}, \boldsymbol{B}, \mathrm{In}$ a control mouse, cell bodies of $\mathrm{SOM}$ neurons are concentrated in s. oriens $(0)$ of $\mathrm{CA} 1$ and $\mathrm{CA} 3$ of the hippocampus and the hilus $(\mathrm{H})$ of the dentate gyrus. A high concentration of SOM fibers and terminals creates a dark band of labeling in s. lacunosum-moleculare (LM) of CA1. Lower concentrations of fibers and terminals are evident in the outer molecular layer $(M)$ of the dentate gyrus. C, D, At $4 \mathrm{~d}$ following pilocarpine-induced status epilepticus, SOM neurons in the dentate hilus are severely depleted. A marked loss of SOM-labeled fibers and terminals is also evident in the molecular layer, consistent with the normal origin of these fibers from SOM neurons in the hilus. Many SOM neurons remain in s. oriens of $\mathrm{CA} 1$, and the band of dense labeling remains in s. lacunosum-moleculare. $\boldsymbol{E}, \boldsymbol{F}, \mathrm{At} 2$ months following pilocarpine-induced seizures, cell bodies of SOM neurons in the hilus remain depleted. However, SOM-labeled fibers and terminals are evident in the outer molecular layer of the dentate gyrus. Scale bars: (in $E$ ) $A, C, E, 200 \mu \mathrm{m}$; (in $\boldsymbol{F}$ ) $B, D, F, 50$ $\mu \mathrm{m} . \mathrm{G}$, granule cell layer.

acquired (excitation spectra $488 \mathrm{~nm}$; $20 \times$ objective) from CA1 and the dentate gyrus of control and pilocarpine-treated SOM-Cre mice.

Densitometric analysis was used to compare the extent of eYFP labeling in control and pilocarpine-treated groups. Measurements were made in two sections from each of four control and four pilocarpinetreated mice at comparable locations in each animal, within $300 \mu \mathrm{m}$ rostral to the injection site at the same mediolateral location as the injection site. Digital images were obtained with an LSM 710 confocal microscope (40× objective) with identical conditions, using sections that had not been scanned previously to eliminate any possible effects of photobleaching. As the brightness of labeled structures was similar across sections, the density measurements reflected primarily the abundance of labeled fibers and boutons. The entire thickness of the molecular layer of the suprapyramidal blade of the dentate gyrus was included in the same image.

The density of labeling was analyzed with morphometric AxioVision software (Version 4.8; Zeiss). In each projected image (16 optical slices), measurements were obtained from rectangular areas of identical size $(50 \times 200 \mu \mathrm{m})$ in the outer, middle, and inner thirds of the molecular layer. The densitometry measurements were analyzed with two-tailed Student's $t$ test, and $p<0.05$ was considered significant.

Acute brain slice preparation and electrophysiology. Coronal brain slices including the dorsal hippocampus were prepared using standard techniques (Mody et al., 1995; Santhakumar et al., 2006). The brain was removed, submerged in cold $\left(<4^{\circ} \mathrm{C}\right)$ artificial CSF (aCSF), and sectioned using a vibratome (VT1000S; Leica Microsystems). Following sectioning, the $350 \mu \mathrm{m}$ slices were stored in $35^{\circ} \mathrm{C}$ aCSF for $30 \mathrm{~min}$ and brought to room temperature for subsequent electrophysiological experiments. The aCSF used during sectioning, storage, and electrophysiological recordings was saturated with $95 \% \mathrm{O}_{2}$ and $5 \% \mathrm{CO}_{2}$ and consisted of the following (in mM): $126 \mathrm{NaCl}, 2.5 \mathrm{KCl}, 2 \mathrm{CaCl}_{2}, 2 \mathrm{MgCl}_{2}, 1.25 \mathrm{NaH}_{2} \mathrm{PO}_{4}, 26$
$\mathrm{NaHCO}_{3}$, and $10 \mathrm{D}$-glucose. Whole-cell pipette solution consisted of the following (in $\mathrm{mm}$ ): 120 $\mathrm{CsMeSO}_{4}, 10 \mathrm{CsCl}, 5$ TEA-Cl, $1.5 \mathrm{MgCl}_{2}, 10$ HEPES, 0.1 EGTA, 2 Na-ATP, 0.5 Na-GTP, and 5 QX-314, pH 7.25-7.30 with $\mathrm{CsOH}, 275$ $285 \mathrm{mOsm}$. A subset of recorded neurons was morphologically identified after visualizing them by addition of $10 \mu \mathrm{M}$ Alexa 555 to the pipette solution. Interneurons and dentate gyrus granule cells were visualized using an upright microscope with a $40 \times$ water-immersion lens and equipped with an infrared-differential interference contrast enhancement. Pipette resistances were 3-5 M $\mathrm{M}$. Recordings were performed using a Multiclamp 700B amplifier (Molecular Devices) and were filtered at $3 \mathrm{kHz}$ and digitized at $10 \mathrm{kHz}$. Neurons were voltage clamped at $+10 \mathrm{mV}$ and recordings were performed at $32-33^{\circ} \mathrm{C}$. SR 95531 and all other chemicals were purchased from Tocris Bioscience with the exception of picrotoxin (Sigma-Aldrich).

Patterned optical stimulation. Patterned illumination was provided by a $100 \mathrm{~mW} 488$ diode laser (Coherent) routed through a spatial light modulator (SLM) system (Phasor; Intelligent Imaging Innovations). By modulating the phase of the Coherent laser light, a diffraction pattern displayed on an LCOS chip can create user-defined patterns of illumination in the specimen plane (Vaziri and Emiliani, 2012). We used parallelograms of illumination with dimensions of $50 \times 100 \mu \mathrm{m}$ in the specimen plane of a $40 \times /$ N.A. 0.9 objective. To stimulate ChR2-expressing neural elements, these shapes were positioned at the indicated locations (s. oriens, s. lacunosum-moleculare, dentate gyrus molecular layer, or hilus) with the long axis oriented parallel to the boundaries of the layer in question. Illumination duration ( $1-5 \mathrm{~ms}$ ) was controlled by electrically triggering the diode laser. Power levels at the objective focal plane varied between 1.5 and $2.7 \mathrm{~mW}$. The laser illumination and duration of exposure were kept within a very narrow range when comparing responses from region to region, slice to slice, and among animals. Post hoc analyses demonstrated no statistically significant difference in the average stimulus duration or intensity in the control and pilocarpine groups ( $n=7$ and 8 cells, respectively). (Stimulus duration: control $=2.7 \pm 0.81$ $\mathrm{ms}$; pilocarpine-treated $=3.0 \pm 0.76 \mathrm{~ms} ; p=0.8$. Total stimulus intensity measured from the objective: control $=2.7 \pm 0 \mathrm{~mW}$; pilocarpinetreated $=2.59 \pm 0.11 \mathrm{~mW} ; p=0.35$, two-tailed Student's $t$ test.)

Analysis of electrophysiology and optical stimulation. Optically evoked electrophysiological responses were analyzed in PCLAMP10, and IPSCs were detected with custom routines written in LabView. Statistical comparisons involving two sample comparisons used a two-tailed Student's $t$ test for samples with unequal variance, while statistics involving multiple comparisons relied on ANOVA with post hoc Nemenyi test.

\section{Results}

Time course study reveals reemergence of SOM axon terminals in pilocarpine-treated mice

In the normal mouse hippocampal formation, the cell bodies of SOM-expressing neurons are concentrated in the hilus of the dentate gyrus and s. oriens of the hippocampus (Fig. 1A), whereas their axon terminal fields are localized in the outer two-thirds of the molecular layer and throughout s. lacunosum-moleculare, respectively (Fig. $1 A, B$ ). The SOM axonal plexus is particularly dense in s. lacunosum-moleculare of CA1 in the mouse (Fig. 1A). While SOM neurons in the hippocampal formation are recog- 
nized as quite vulnerable to damage in epilepsy, we and others have noted apparent inconsistencies between the extent of SOM neuronal loss in the dentate hilus and the relative abundance of SOM axon terminals in the molecular layer during the chronic stage in several animal models of epilepsy. We thus conducted a time course study of changes in SOM-expressing neurons following pilocarpine-induced status epilepticus to clarify the sequence and timing of these changes. In the mouse pilocarpine model, a decrease in hilar SOM neurons was clearly evident throughout the dentate gyrus by $24 \mathrm{~h}$ following status epilepticus. By $4 \mathrm{~d}$ following status epilepticus, SOM-labeled cell bodies in the hilus and terminal fields in the molecular layer were both substantially decreased (Fig. 1C,D). In the dorsal (ros-

tral) dentate gyrus, the loss of SOM neurons in the hilus was extensive and often nearly complete (Fig. 1C), and the axonal plexus in the outer molecular layer was also severely depleted (Fig. 1C,D), consistent with these fibers originating from hilar SOM neurons. However, some hilar SOM neurons were preserved in more caudal (ventral) regions of the dentate gyrus (data not shown), as has been described previously in GFP-expressing inhibitory neurons (GIN) mice (Zhang et al., 2009).

Because of the particularly extensive loss of hilar SOM neurons in the dorsal dentate gyrus in the mouse pilocarpine model, we focused on this region to determine whether changes in SOM labeling occurred over time, beginning with a virtual absence of these neurons and their axon terminal fields immediately after status epilepticus. Indeed, at later time points (1-3 months), labeled terminals in the dentate molecular layer progressively increased, even though the cell bodies of SOM neurons in the hilus remained depleted (Fig. 1E,F). By 2 months, a substantial plexus of labeled fibers extended throughout the outer half of the molecular layer, with the highest concentration of fibers in the outer third of the layer (Fig. $1 F$ ). Further study revealed an interesting pattern and progression of labeling. As early as 1-2 weeks after status epilepticus, SOM-labeled fibers and punctate structures were evident in the outermost part of the dentate molecular layer, immediately adjacent to the dense band of SOM labeling in s. lacunosum-moleculare (Fig. 2A). When viewed at higher magnification, many of these labeled fibers were vertically oriented, suggesting that they could be extending downward from s. lacunosum-moleculare (Fig. 2A). This pattern was unexpected since, if the fibers originated primarily from remaining hilar SOM neurons, they would be expected to extend from the hilus through the granule cell layer and into the molecular layer or ramify from persisting fibers in the molecular layer. Such projections from remaining hilar neurons have been described previously in GIN mice following status epilepticus (Zhang et al., 2009), and we have observed similar patterns in caudal regions of the dentate gyrus in GIN mice in which GFP-labeled fibers can be detected readily (C.R. Houser and C.S. Huang, unpublished findings).

We also observed that, in rostral regions of the dentate gyrus, SOM-labeled fibers appeared first and were most numerous in the suprapyramidal (inner) blade of the dentate gyrus (Fig. 2B). As the abundance of SOM-labeled fibers increased, some fibers extended into the molecular layer of the infrapyramidal (outer) blade (Fig. 2B), suggesting a progressive growth of fibers into the region. By 2-3 months, SOM-labeled fibers were evident in the outer regions of the molecular layer in both blades of the dentate gyrus (Fig. 2C).

The sequence and patterns of these changes led to the seemingly unlikely hypothesis that remaining SOM neurons in $\mathrm{s}$. oriens of CA1, which normally form a dense band of SOMlabeled fibers in s. lacunosum-moleculare of CA1, could sprout and contribute to the SOM innervation of the molecular layer of the dentate gyrus.

Numerous attempts to use standard tracers to demonstrate such sprouting proved unsuccessful due to difficulties in obtaining layer- and cell type-specific labeling. A method was needed to label SOM neurons in s. oriens selectively and demonstrate their axonal plexus. This was achieved through use of SOM-Cre mice and the selective labeling of SOM neurons in $\mathrm{s}$. oriens through viral delivery of a Cre-dependent ChR2-eYFP construct to s. oriens. This allowed comparisons of the axon terminal fields of these neurons in pilocarpine-treated and control mice.

The patterns of SOM-expressing neurons in the hilus and s. oriens of CA1 in the normal and pilocarpine-treated SOM-Cre mice used for virus injections (described in the following sections) were similar to those observed in the time course study in C57BL/ 6 mice. Cell counts of SOM neurons in these regions of the dorsal hippocampal formation demonstrated a statistically significant difference between groups in the hilus (means $\pm \mathrm{SEM}=16.50 \pm 1.17$ in controls and $3.63 \pm 1.02$ in pilocarpine-treated; $p<0.001$ ) but not in s. oriens (means $=$ $29.88 \pm 3.76$ in controls and $22.80 \pm 2.79$ in pilocarpinetreated; $p<0.15 ; n=4$ mice and 8 sections per condition). This represented a $78.0 \%$ decrease of SOM neurons in the dentate hilus and a $23.7 \%$ decrease of SOM neurons in $\mathrm{s}$. oriens of CA1 in the pilocarpine-treated mice. Thus, although a slight decrease in SOM neurons was evident in s. oriens of this mouse model, as has been found for GABA neurons in the rat pilocarpine and kainate models (Houser and Esclapez, 1996; Morin et al., 1998; Dinocourt et al., 2003), the extent of cell loss in s. oriens was much less than that in the hilus, and a high percentage of SOM neurons remained in s. oriens in the pilocarpine-treated mice used in the current study. 

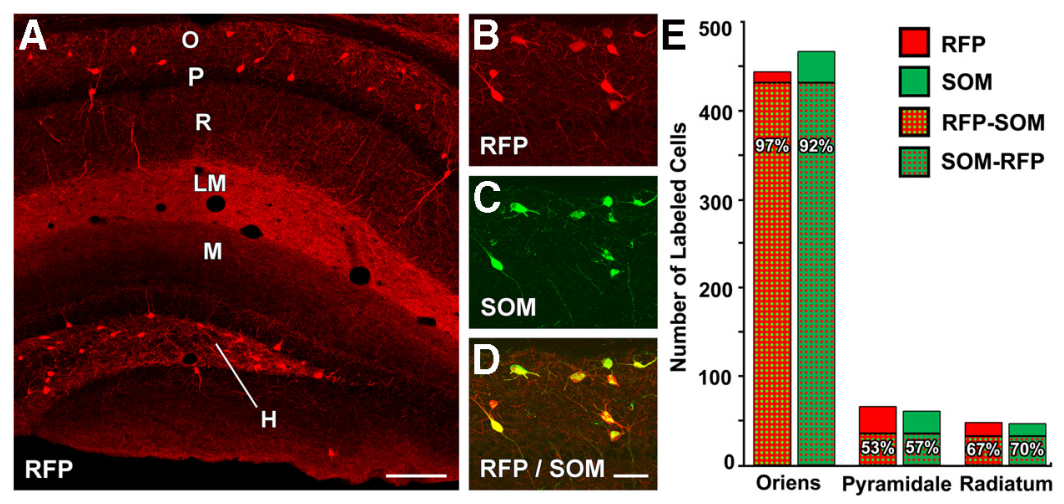

Figure 3. Localization of endogenous RFP and SOM immunoreactivity in SOM-Cre-Ai9 mice. $A$, RFP, a reporter of Cre expression in these mice, is present in the cell bodies of numerous neurons in s. oriens $(0)$ in $C A 1$ and the dentate hilus $(H)$, with relatively few labeled neurons within s. pyramidale (P) and s. radiatum (R). A dense band of labeled fibers and terminals is evident in $\mathrm{s}$. lacunosum-moleculare ( $L M)$, and more moderate labeling of fibers is present in the outer molecular layer $(M)$ of the dentate gyrus. This labeling closely resembles the normal patterns of SOM immunoreactivity (Fig. 1A). $\boldsymbol{B}-\boldsymbol{D}$, In sections processed for SOM immunohistochemistry, the majority of RFP-labeled neurons in s. oriens are also immunolabeled for $\mathrm{SOM}$, as demonstrated by the merged images. All cell bodies in this region of s. oriens are double labeled. $\boldsymbol{E}$, Quantitative analysis of single- and double-labeled cells in CA1 demonstrated a high correspondence between RFP and SOM labeling in s. oriens, where the majority of RFP-labeled cells were located. Lower percentages of double-labeled neurons were found in s. pyramidale and s. radiatum, but the number of neurons in these regions was substantially smaller than in s. oriens. Scale bars: $A, 200 \mu \mathrm{m} ; \boldsymbol{B}-\boldsymbol{D}, 50 \mu \mathrm{m}$.

\section{Neurons in s. oriens of SOM-Cre mice are selectively labeled for SOM}

To verify the specificity and selectivity of Cre-expression in SOM neurons in the SOM-Cre mice, these mice were bred with the Ai9 reporter mouse. The offspring of these mice expressed tdTomato, an RFP variant, in Cre-expressing neurons. At low magnification, the RFP labeling closely resembled the normal pattern of SOM labeling, with the highest concentration of RFP-labeled cell bodies in the dentate hilus and s. oriens of the hippocampus (Fig. $3 A$ ). In addition, a dense band of terminal labeling was evident in s. lacunosum-moleculare of CA1, and diffuse labeling of terminal fields was also present in the outer part of the dentate molecular layer (Fig. $3 A$ ). This labeling closely resembled the normal immunohistochemical labeling of SOM in the mouse (Fig. 1A).

Immunohistochemical labeling of SOM was used to determine the correspondence between endogenous RFP labeling and SOM immunoreactivity in these mice. Colocalization of these markers was high in cell bodies of s. oriens of CA1 (Fig. $3 B-D$ ) and the hilus. Quantitative analysis of SOM- and RFP-labeled cell bodies in CA1 verified that the RFP-labeled neurons, presumably expressing Cre, were SOM neurons. Approximately $96.8 \%$ of RFP-labeled neurons in s. oriens expressed SOM, whereas $\sim 92.1 \%$ of SOM neurons were labeled for RFP in this region $(n=481$ total labeled cells analyzed; Fig. 3E). In s. pyramidale and s. radiatum, the correspondence between the two markers was lower than that in s. oriens. Lower percentages of RFP-labeled cells were immunolabeled for SOM in s. pyramidale $(53.0 \%)$ and s. radiatum (66.7\%; Fig. 3E). Likewise, lower percentages of SOM-labeled neurons were labeled for RFP in s. pyramidale $(57.4 \%)$ and s. radiatum $(69.6 \% ; n=92$ and 62 total labeled cells analyzed in the two layers, respectively; Fig. $3 E$ ). While no labeled neurons were observed within s. lacunosum-moleculare, a few labeled neurons were observed at the border with s. radiatum, and these neurons were included with the limited number of labeled cells in s. radiatum.

Detailed analysis of colocalization was limited to CA1 for this study, and, while strong correspondence between RFP and SOM labeling was found in s. oriens of CA1 and the hilus, a general survey suggested that colocalization could be less in some other hippocampal regions. Scattered neurons in s. radiatum of CA3 ramidal neurons in s. pyramidale were devoid of eYFP labeling (Fig. $4 A, B$ ), thus demonstrating the high specificity of the AAV Cre-dependent labeling. In addition, a dense plexus of eYFPlabeled fibers and terminals was evident in s. lacunosummoleculare of CA1 (Fig. 4A), and this labeling closely resembled the normal SOM labeling of axons and terminals in this region in the mouse. A few labeled fibers were evident in the outer molecular layer of the dentate gyrus (Fig. $4 A$ ), suggesting that a very limited number of fibers from SOM neurons in s. oriens cross the hippocampal fissure and enter the molecular layer of the dentate gyrus in normal animals. Such labeling occurred in the absence of any labeling of the dentate hilus (Fig. 4A).

Despite the presence of Cre-expressing SOM neurons in the hilus of normal animals, as demonstrated in the SOM-Cre-Ai9 mouse (Fig. 3A), these hilar SOM neurons were not labeled with eYFP following viral injections directed at s. oriens in the normal animals, with the exception of one animal discussed below. Such light microscopic examination, conducted on all experimental material, offered clear verification of whether the transfection remained restricted to neurons in s. oriens.

Double labeling with SOM immunohistochemistry confirmed that essentially all ChR2-eYFP-expressing neurons were labeled for SOM (Fig. 4B-D), although not every SOM-labeled neuron was labeled with eYFP. These findings demonstrated both cell type and regional specificity of ChR2-eYFP labeling in normal SOM-Cre mice.

The parameters for AAV injections were established in normal animals and maintained for control and pilocarpine-treated mice. The resulting extent of cell body labeling in s. oriens following the AAV injections was similar in the three groups of animals. At 3 weeks after viral injection at a single site in the dorsal s. oriens, near the center of CA1, eYFP labeling of cell bodies and their dendritic processes was strongest near the site of injection and extended a considerable distance mediolaterally and rostrocaudally. At the level of injection, eYFP-expressing cell bodies were evident throughout s. oriens of CA1 and occasionally extended for a short distance into s. oriens of CA2 laterally and the subiculum medially, for a total distance of $2.0-2.5 \mathrm{~mm}$. EYFPexpressing cell bodies extended rostrally and caudally from the 
injection site for a total distance of 1.2$1.65 \mathrm{~mm}($ mean $=1.3 \mathrm{~mm})$ in the normal/ control mice and $1.2-1.5 \mathrm{~mm}$ (mean $=$ $1.3 \mathrm{~mm}$ ) in the pilocarpine-treated animals. The extent of eYFP-expressing fibers in the normal, control, and pilocarpine-treated mice closely paralleled the extent of the cell body labeling.

\section{ChR2-eYFP labeling demonstrates a reorganized axonal plexus in pilocarpine-treated mice}

To compare the axonal patterns of eYFPlabeled neurons in s. oriens of pilocarpine-treated and control animals, AAV injections were made in pilocarpinetreated SOM-Cre mice at 5 weeks following pilocarpine-induced status epilepticus and in age-matched control animals, and the neuroanatomical studies were conducted at 3 weeks following injection. Labeling in control mice was essentially the same as that obtained in normal animals, with extensive labeling of axon terminals in s. lacunosum-moleculare (Fig. $5 A$ ). As observed in normal animals, the strong band of eYFP labeling ended abruptly at the hippocampal fissure, although a few scattered axons were evident in the molecular layer of the dentate gyrus, and these often appeared to extend from fibers in s. lacunosum-moleculare (Fig. $5 A, C)$.

In contrast, in the pilocarpine-treated mice, extensive eYFP labeling was evident in the molecular layer of the suprapyramidal blade of the dentate gyrus (Fig. 5B). This labeling was strongest in the outer third of the molecular layer but substantial labeling extended throughout approximately two-thirds of the molecular layer (range $=60-$ $90 \%$ ) in the four animals used for detailed morphological analysis. This analysis was made near the level of the injection, where eYFP labeling was strongest. As in the control mice, no labeling of cell bodies was evident in the hilus (Fig. 5B), presumably because the injection site was limited to s. oriens, as in the control animals, but also because few hilar neurons remained in the hilus of the pilocarpine-treated mice. At higher magnification, in the molecular layer of the suprapyramidal blade of the dentate gyrus, a rich plexus of fine fibers was evident in the pilocarpine-treated animals (Fig. $5 D, E$ ), and this contrasted sharply with the very limited number of labeled fibers in the molecular layer of control animals (Fig. 5C). The labeled axons in the pilocarpine-treated mice were characterized by numerous periodic punctate structures, with thin intervening axonal segments, and thus had the classic appearance of en passant axon terminals (Fig. $5 E$ ). In addition, in medial regions of the infrapyramidal blade of the dentate gyrus, labeled fibers were also present in the outer part of the molecular layer and appeared to be emerging from the medial regions of s. lacunosum-moleculare, curving around the crest of the dentate gyrus and extending into the outer molecular layer (Fig. 6).

Densitometry measurements provided a semiquantitative description of the changes in eYFP labeling in the dentate molecular layer in the pilocarpine-treated mice. The results demonstrated significant differences in the density of eYFP-labeled fibers in each one-third of the molecular layer in the pilocarpinetreated mice compared with controls $(p<0.0002,0.0001$, and 0.036 for the outer, middle, and inner one-third, respectively; $n=$ 8 sections and 4 mice per group; Table 1). When densitometry values were converted to percentages of control values, increases in the pilocarpine-treated group were $252.1,214.6$, and $38.1 \%$ in the outer, middle, and inner third of the molecular layer, respectively (Table 1). These results were consistent with the qualitative analysis.

The findings demonstrated that, in pilocarpine-treated mice, axons of SOM neurons in s. oriens of CA1 extended beyond their normal termination sites in s. lacunosum-moleculare of CA1 and formed an aberrant innervation of the molecular layer of the dentate gyrus, a region that was previously depleted of its normal SOM innervation because of loss of hilar SOM neurons.

\section{Electron microscopy demonstrates synaptic contacts of} reorganized axon terminals in pilocarpine-treated mice Electron microscopic studies in the pilocarpine-treated animals confirmed that the eYFP-labeled processes in the dentate molecular layer were axons and axon terminals. In the molecular layer, immunogold labeling of eYFP was most highly concentrated around the perimeter of the axon terminals, demonstrating localization of ChR2-eYFP at or near the plasma membrane (Fig. $7 A$ ). The labeled axon terminals contained numerous synaptic vesicles and mitochondrial profiles, and formed distinct symmetric synaptic contacts on unlabeled dendritic profiles (Fig. 7A-E). Thus the labeled terminals exhibited the ultrastructural features of normal GABAergic axon terminals. The eYFP-labeled termi- 

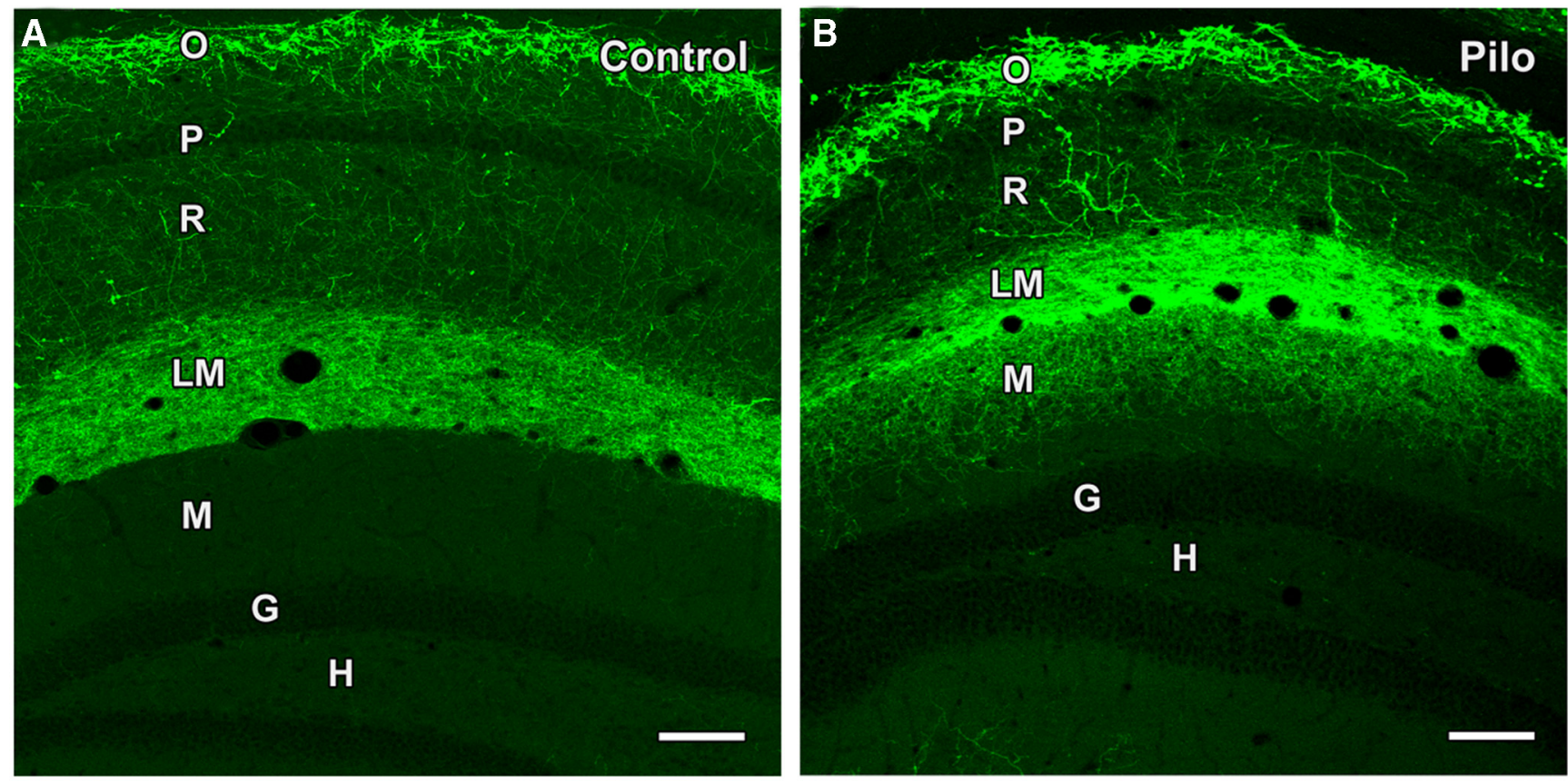

H
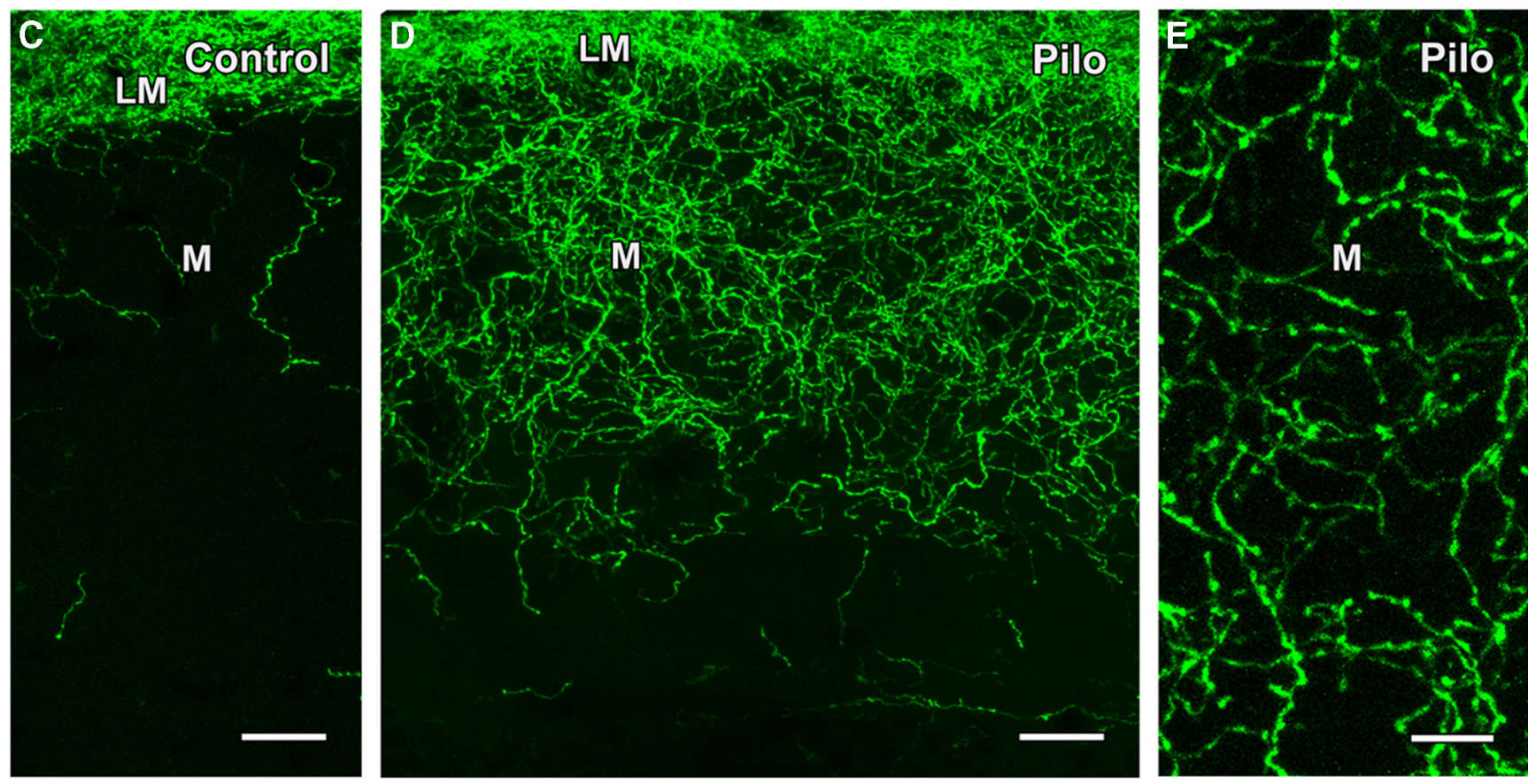

Figure 5. Comparison of ChR2-eYFP labeling in control and pilocarpine (Pilo)-treated mice following viral vector injection in s. oriens of SOM-Cre mice. $A, B$, In a control mouse, numerous neurons in s. oriens ( $(0)$ of CA1 are labeled for eYFP, with very limited cell body labeling in s. pyramidale (P) and s. radiatum (R). A dense plexus of labeled fibers is evident in s. lacunosum-moleculare (LM) but does not extend into the adjacent molecular layer (M) of the dentate gyrus. No labeling is evident in the granule cell layer (G) or hilus (H). In a pilocarpine-treated mouse, similar eYFP labeling is evident in s. oriens and s. lacunosum moleculare, but, in contrast to the control, substantial labeling extends into the outer molecular layer of the dentate gyrus. $\boldsymbol{C}, \boldsymbol{D}$, At higher magnification, limited numbers of eYFP-labeled fibers are present in the outer molecular layer in the control mouse. In contrast, a rich plexus of labeled fibers is evident throughout the outer two-thirds of the molecular layer in a pilocarpine-treated mouse. $E$, Labeled fibers in the molecular layer of a pilocarpine-treated mouse exhibit numerous small swellings separated by thin labeled segments, suggesting axons with en passant terminals. Scale bars: $A, B, 100 \mu \mathrm{m} ; C, D, 25 \mu \mathrm{m} ; \boldsymbol{E}, 10 \mu \mathrm{m}$.

nals formed synaptic contacts primarily with unlabeled dendritic shafts (Fig. 7A-C). However, synaptic contacts were also established with dendritic spines, and these spines frequently received asymmetric synaptic contacts from unlabeled axon terminals (Fig. $7 D, E$ ). In a systematic analysis of a series of eYFPlabeled structures in the dentate molecular layer in which the postsynaptic structures could be identified ( $n=164), 67.7 \%$ formed symmetric synaptic contacts with dendritic shafts $(n=$
111), and $32.3 \%$ formed symmetric synapses with dendritic spines $(n=53)$. Such localization on both dendritic shafts and spines is consistent with synaptic contacts of normal SOM neurons with dendrites of dentate granule cells (Milner and Bacon, 1989; Leranth et al., 1990; Katona et al., 1999; Zhang et al., 2009).

Electron microscopic studies also demonstrated immunogoldlabeled cell bodies and dendrites in s. oriens (Fig. $7 F, G$ ). Immunogold labeling of dendritic profiles was frequently located along 
their surface (Fig. $7 F, G$ ) and outlined the contours of the labeled processes. The labeled processes received both asymmetric and symmetric synaptic contacts (Fig. $7 F, G)$. These findings provide morphological support for incorporation of the labeled SOM neurons in functional circuits in the pilocarpine-treated animals, with demonstrations of synaptic contacts on their dendrites and cell bodies in s. oriens and the formation of synaptic contacts with probable granule cells in the dentate gyrus.

\section{Patterned optogenetic stimulation demonstrates functional synaptic connections}

To confirm that the reorganized fibers of s. oriens interneurons formed functional GABAergic synaptic connections with dentate granule cells in the pilocarpine-treated mice, SLM-based patterned optical stimulation (Lutz et al., 2008) was used to activate ChR2 and thus stimulate the labeled neurons and their axons and terminals. Recordings were made in hippocampal slices obtained from normal, control (receiving saline rather than pilocarpine injections), and pilocarpine-treated mice. No differences in labeling or functional responses were detected between ChR2-labeled normal and control mice, and thus these groups will be referred to as control mice in subsequent descriptions.

To determine the functional effects of ChR2 expression in interneurons of s. oriens and establish the validity and spatial selectivity of the optical stimulation methods, interneurons of s. lacunosum-moleculare of CA1 of normal mice were selected as positive controls. These interneurons were chosen because they normally receive direct GABAergic inputs from SOM neurons in s. oriens (Elfant et al., 2008; Lovett-Barron et al., 2012). Granule cells in the dentate gyrus could not serve as positive controls in the control animals because they do not receive substantial input from SOM interneurons in s. oriens.

Interneurons of s. lacunosum-moleculare of CA1 were recorded in whole-cell mode and voltage clamped at $+10 \mathrm{mV}$ with low $\mathrm{Cl}^{-}$pipette solutions, conditions under which $\mathrm{GABA}_{\mathrm{A}}$ receptor-mediated currents are outward. Patterned laser stimulation with blue light was first applied by positioning a parallelogram of illumination of $50 \times 100 \mu \mathrm{m}$ in either s. oriens or s. lacunosum-moleculare with the long axis parallel to the layer boundaries to stimulate the ChR2-eYFP-labeled cell bodies and dendrites in this region (Fig. 8). Light stimuli in s. oriens evoked IPSCs in three of five interneurons with brief (1-5 ms) light pulses $(15.3 \pm 6.3 \mathrm{pA}, n=3$ neurons in 3 mice; these and all subsequent electrophysiological values indicate mean IPSC amplitudes \pm SEM). These responses were blocked by the $\mathrm{GABA}_{\mathrm{A}}$ receptor antagonists SR-95531 or picrotoxin $(\sim 100 \mu \mathrm{M})$, indicating that the inhibitory responses were $\mathrm{GABA}_{\mathrm{A}}$ receptor mediated (Fig. 8). Similar optical stimuli were then applied to s. lacunosum-moleculare to stimulate the abundant ChR2-labeled axons and terminals in this region, and large IPSCs were present in the same interneurons (Fig. 8; $105 \pm 59 \mathrm{pA}, n=3$ neurons in 3 mice). Recordings were then made from dentate granule cells in slices from the same animals (and in some instances from the same slice), and negligible inhibitory responses were obtained from stimulation of either labeled neurons in s. oriens or their fibers in s. lacunosum-moleculare (Fig. 8; $0.6 \pm 0.6$ and $1.5 \pm 1.5$
Table 1. Comparison of mean intensity of labeling for eYFP in the dentate molecular layer of control versus pilocarpine-treated mice

\begin{tabular}{lllll}
\hline & \multicolumn{2}{l}{$\begin{array}{l}\text { Intensity of labeling } \\
\text { (mean } \pm \text { SEM) }\end{array}$} & $\begin{array}{l}\text { Percentage difference } \\
\text { in pilocarpine versus }\end{array}$ \\
\cline { 2 - 5 } Region of molecular layer & Control & Pilo & control mice & $p$ value \\
\hline Outer third & $14.79 \pm 1.61$ & $52.07 \pm 5.43$ & $+252.1 \%$ & 0.0002 \\
Middle third & $12.54 \pm 1.52$ & $39.44 \pm 3.96$ & $+214.6 \%$ & 0.0001 \\
Inner third & $12.47 \pm 1.48$ & $17.22 \pm 1.41$ & $+38.1 \%$ & 0.036 \\
\hline
\end{tabular}

pA for s. oriens and s. lacunosum-moleculare, respectively; $n=6$ dentate granule cells from 4 mice). These results established the functionality of ChR2 expression, and the validity and specificity of the optical stimulation methods, with demonstrations of both positive and negative responses in the expected locations in control animals.

Similar recordings were then made in dentate granule cells in control and pilocarpine-treated animals. For both groups, SLMshaped laser illumination was delivered with the identical rectangular pattern described above, using similar intensities and durations (see Materials and Methods), to four laminar locations in each slice (Fig. 9A): (1) s. oriens of CA1 to activate the somata and dendrites of ChR2-labeled SOM neurons; (2) s. lacunosum-moleculare to activate fibers in the dense plexus of labeled axons in this region; (3) dentate molecular layer to activate reorganized axon terminals within the region in pilocarpine-treated animals but not in controls; and (4) the dentate hilus where no responses were anticipated in either control or pilocarpine animals, due to lack of ChR2 labeling in this region in all animals. Comprehensive light microscopic analysis was performed post hoc in all slices in which recordings were obtained.

When recording in slices from the pilocarpine and control animals, the experimenter was blind to the extent of eYFP labeling in each slice, and this allowed unbiased recordings in the pilocarpinetreated and control animals. During such recording, an additional control condition was unexpectedly obtained. In a slice from one control mouse, optical stimulation of both the hilus and molecular layer elicited sizeable mean IPSC amplitudes (34 and 61 pA, respectively) in a granule cell. Virtually no response was observed in the same cell following stimulation of s. lacunosum-moleculare or s. oriens. Interestingly, in this slice, post hoc confocal microscopy revealed eYFP-labeled neurons in the hilus, in addition to labeling in $\mathrm{s}$. oriens and s. lacunosum-moleculare. The most likely explanation for the unanticipated labeling is that the injection site extended 

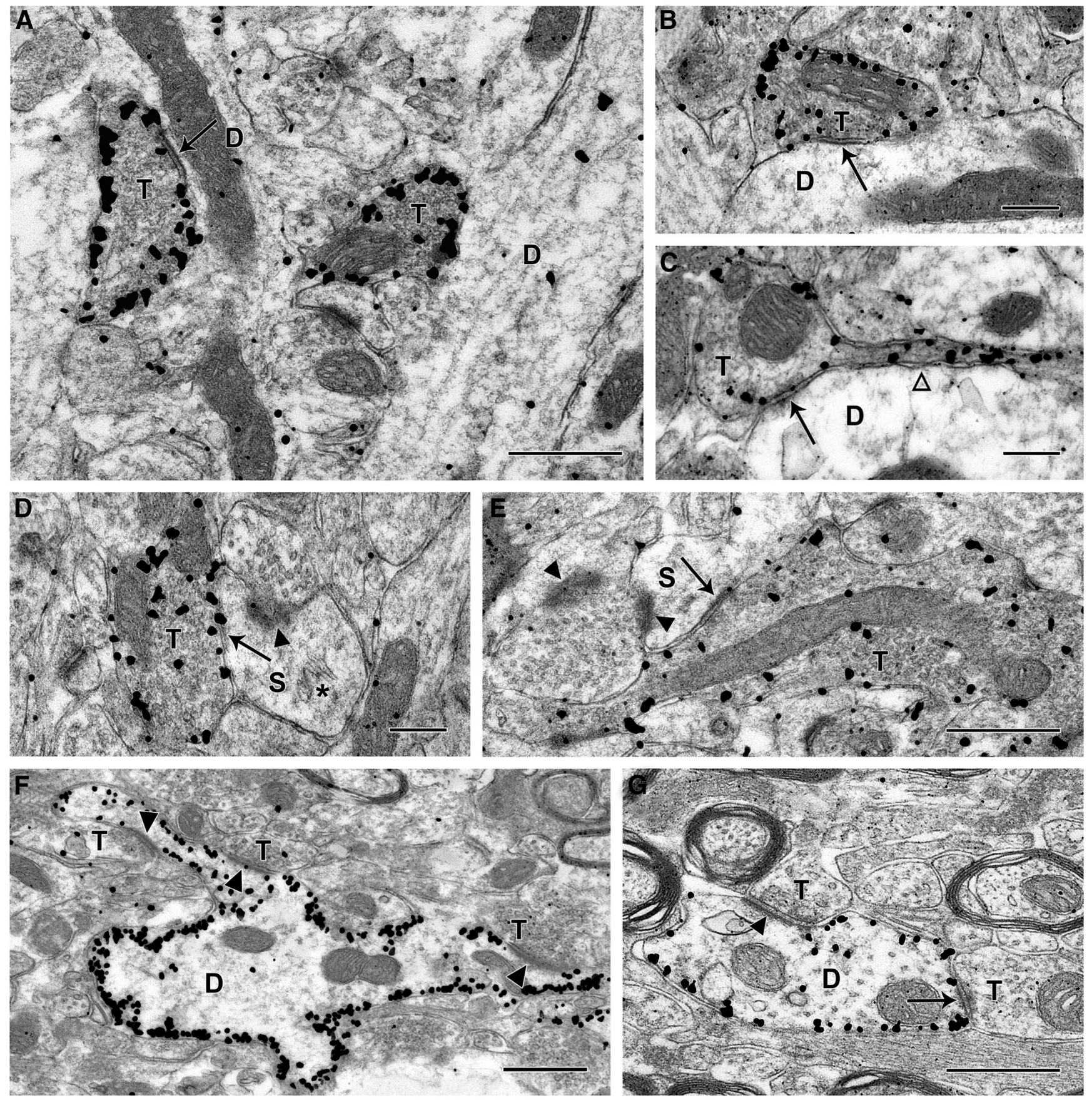

Figure 7. Electron micrographs of immunogold labeling of eYFP at 3 weeks following viral-mediated transfection of ChR2-eYFP in s. oriens of CA1 in a pilocarpine-treated SOM-Cre mouse. $A-C$ Immunogold-labeled terminals $(T)$ in the dentate molecular layer form distinct symmetric synaptic contacts (arrows) with medium to small dendritic shafts (D). Immunogold particles are frequently concentrated near the periphery of the labeled axon terminals. The labeled terminals contain mitochondrial profiles and numerous synaptic vesicles, consistent with functional terminals. $C$, A labeled axon terminal is in continuity with the thin preterminal segment of its axon (open arrowhead). $\boldsymbol{D}, \boldsymbol{E}$, eYFP-labeled terminals also form symmetric synaptic contacts (arrows) with dendritic spines (S) in the dentate molecular layer. These spines form asymmetric synaptic contacts (arrowheads) with unlabeled terminals. In $\boldsymbol{D}$, the spine contains a spine apparatus $(*$ ), and in $\boldsymbol{E}$, the labeled terminal is relatively large and forms an en passant synapse with the spine $(S) . \boldsymbol{F}, \boldsymbol{G}$ In $\mathrm{s}$. oriens of CA1, eYFP-labeled dendrites appear outlined by immunogold particles, which are located near the inner face of the plasma membrane. These dendrites commonly received synaptic contacts. $\boldsymbol{F}$, Unlabeled terminals (T) form asymmetric synapses (arrowheads) with a labeled dendrite, and two of these contacts are with an elongated spine-like process that extends from the larger dendritic shaft. $G$, A labeled dendrite receives both an asymmetric (arrowhead) and a probable symmetric (arrow) synaptic contact from unlabeled axon terminals. Scale bars: $\boldsymbol{A}, \boldsymbol{E}, \boldsymbol{F}, \mathbf{G}, 0.5 \mu \mathrm{m} ; \boldsymbol{B}-\boldsymbol{D}, 0.25 \mu \mathrm{m}$.

deeper than s. oriens and the viral vector reached the dentate gyrus, either directly or by diffusion. Based on evidence of hilar neuron labeling in the slice, recordings from this cell were excluded from the dataset for control animals. However, the recordings provided both positive and negative control data; IPSCs in the granule cell were obtained in response to optical stimulation of hilar neurons that normally provide inhibition at granule cell dendrites, but not following similar stimulation of labeled profiles in s. lacunosummoleculare or oriens that normally do not innervate dentate granule cells.

In all other slices from control mice $(n=4$ mice), laserevoked IPSCs in dentate granule cells were extremely small or 
absent following stimulation in any of the four locations (Fig. 9B): Means \pm SEM, s. oriens $0.9 \pm 0.9$; s. lacunosummoleculare $1.5 \pm 1.5$; molecular layer $1.5 \pm 1.5$; and hilus $2.1 \pm 1.7 \mathrm{pA}(n=4,6$, 6 , and 5 cells, respectively). This result is consistent with the light microscopic data indicating a lack of innervation of dentate granule cells by SOM neurons in s. oriens and a lack of ChR2-labeled neurons in the dentate hilus which, if present, would have been expected to produce clear inhibitory responses in the granule cells of normal mice.

In contrast, in granule cells from all pilocarpine-treated animals $(n=4$ mice), laser-evoked IPSCs were consistently obtained following laminar stimulation in s. oriens, s. lacunosum-moleculare, and the dentate molecular layer (Fig. 9C): Means \pm SEM, s. oriens $26.8 \pm 13.3$; s. lacunosummoleculare $51.4 \pm 14.5$; and molecular layer $54.3 \pm 18.4 \mathrm{pA}(n=10$ cells in each region). Laser-evoked IPSCs were very limited or absent in response to comparable stimulation of the dentate hilus (Fig. 9C): $0.3 \pm 0.3 \mathrm{pA}(n=10$ cells $)$. Nonparametric, multiple-comparison statistical analyses show significant differences between the pilocarpine-treated and control recordings for stimuli in s. lacunosum-moleculare and the dentate molecular layer $(p<0.025$ and 0.05 , respectively, post ANOVA Nemenyi test; Fig. $9 C$ ) as well as within group differences in pilocarpine-treated recordings for stimuli in these same regions as compared with the hilus $(p<0.05$, post ANOVA Nemenyi test).

Following all electrophysiological experiments, the locations of the recorded cells were identified by the Alexa Fluor 555 labeling, and the distributions of eYFP-labeled neurons and processes were determined with confocal microscopy. EYFP-labeled neurons in s. oriens were evident in all slices used for electrophysiology. In all normal and control slices, abundant ChR2-eYFP-labeled fibers were observed in s. lacunosum-moleculare, consistent with axonal projections from the labeled neurons in s. oriens. In these animals, little or no labeling was detected in the molecular layer of the dentate gyrus (except in the one slice with hilar neuron labeling, described above). In contrast, in all slices from pilocarpine-treated animals in which recordings were made, eYFP-labeled fibers were evident in the molecular layer. Although the abundance of the ChR2-eYFPexpressing fibers in the molecular layer of the pilocarpine-treated mice varied slightly, the overall labeling patterns were remarkably consistent among animals and appeared very similar to the labeling observed in the morphological studies. In all but one slice from control mice (described above) and all slices from pilocarpine-treated mice, no labeled neurons were detected in the hilus.

The electrophysiological findings thus demonstrated that SOM neurons in s. oriens formed functional inhibitory synaptic connections with dentate granule cells in pilocarpine-treated mice but not in controls, verified that the inhibitory responses were GABA-mediated, and suggested that the reorganized innervation in the molecular layer was sufficiently robust to be effective within a functional circuit.

\section{Discussion}

Reorganization of a specific class of SOM/GABA axons in a model of epilepsy

The major findings of this study are that SOM/GABA neurons can undergo substantial axonal reorganization, project beyond

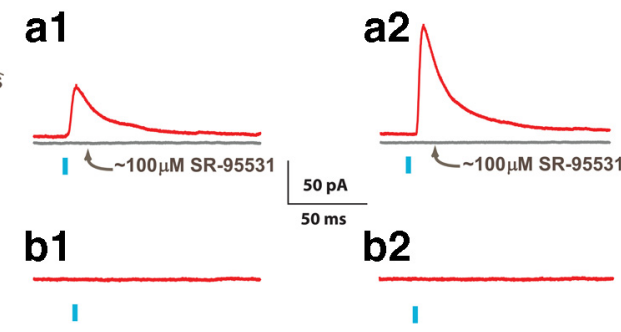

Figure 8. Regional stimulation of $\mathrm{ChR2}$ with patterned illumination in control mice demonstrates that neurons in s. oriens contact interneurons in s. lacunosum-moleculare (LM) but not granule cells $(\mathrm{G})$ in the dentate gyrus. On the left is a schematic illustrating a (he locations of ChR2-expressing neurons in s. oriens (green) and the stimulation regions targeted by blue laser light Whole-cell recordings from either LM interneurons (red pipette, site a) or dentate gyrus granule cells (red pipette, ions (1, oriens; 2, LM) in an LM interneuron (a1 and a2) and in a dentate gyrus granule cell (b1 and b2). Following application of 100 ponse to laser pulses was abolished (gray traces in a1 and a2).

their normal innervation territory, and form functional but aberrant circuitry in a mouse model of epilepsy. Clear evidence for sprouting of GABAergic axons has been difficult to obtain in part because such reorganization has often appeared to be restricted to local sites, thus suggesting sprouting of remaining GABA fibers in regions that they normally innervate. In contrast, the current findings provide evidence for axonal sprouting of a specific group of SOM-expressing neurons beyond their normal termination sites. This may be the first demonstration of extensive axonal growth of GABA neurons into a new territory in an epilepsy model.

Classical oriens lacunosum-moleculare (O-LM) cells (Lorente de Nó, 1934; McBain et al., 1994; Sik et al., 1995) are likely to be the major source of the reorganized fibers, based on the exuberant ChR2-eYFP-labeled axonal plexus in s. lacunosum-moleculare in normal and control mice. Other studies in which s. oriens neurons have been optogenetically labeled in either SOM-Cre or nicotinic acetylcholine receptor $\alpha 2$-subunit (Chrna2)-Cre mice have demonstrated similar patterns of labeling and also concluded that O-LM cells are a major class of the labeled neurons (Leão et al., 2012; Royer et al., 2012). However, contributions from other SOM-expressing neurons cannot be ruled out, including those that innervate s. lacunosum-moleculare but have their cell bodies in s. pyramidale and s. radiatum (Oliva et al., 2000), SOM-expressing bistratified cells that normally innervate s. radiatum and s. oriens (Halasy et al., 1996; Somogyi and Klausberger, 2005; Royer et al., 2012), and septalprojecting neurons in CA1 that express SOM (Gulyás et al., 2003; Jinno et al., 2007).

\section{Light microscopic and ultrastructural evidence for ChR2- eYFP on axon terminals}

ChR2-eYFP-labeled fine fibers and en passant boutons in the dentate molecular layer closely resembled the small-diameter axons and terminals that are characteristic of O-LM cells in the hippocampus (Katona et al., 1999). These labeled profiles were distinctly different from the abnormal axonal enlargements that have been observed in some instances in the cerebral cortex following high-level, long-term ChR2 expression (Miyashita et al., 2013). Electron microscopy confirmed the normal ultrastructure of the ChR2-eYFP-labeled axon terminals, and, importantly, demonstrated that they formed distinct symmetric synapses, characteristic of GABAergic synapses, on dendrites in the dentate molecular layer. The relatively short-term expression of ChR2 in adult mice and a relatively weak promoter may have contributed to the normal morphology of the labeled axons in the present study. However, while optogenetic methods have great potential for identifying morphologically altered circuits and their func- 

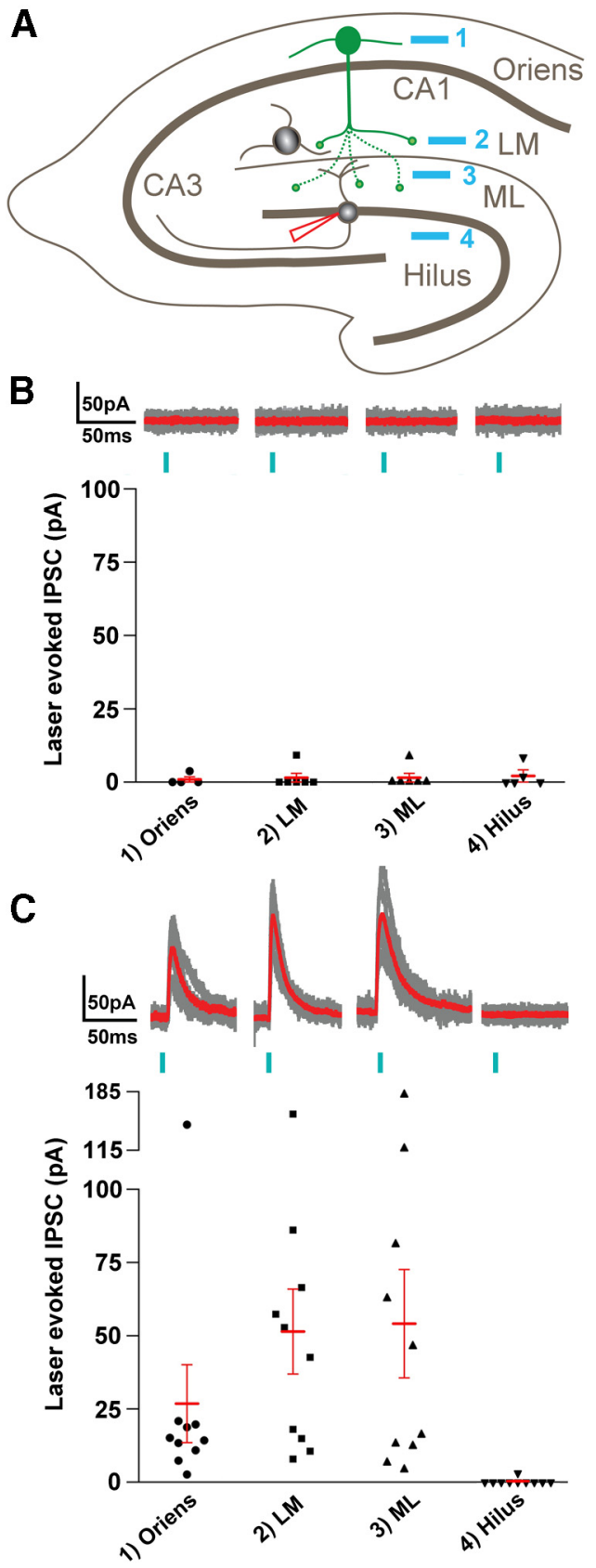

Figure 9. Reorganization of GABAergic circuitry in pilocarpine-treated mice. $A$, Schematic illustrating the patterned illumination laser stimuli in s. oriens (site 1), s. lacunosum-moleculare of CA1 (LM, site 2), dentate molecular layer (ML, site 3), and hilus (site 4), respectively, as well as whole-cell recordings used in granule cells (red pipette). $\boldsymbol{B}$, Summary of stimulating these different locations in control mice ( $n=4-6$ cells). Top, Each part shows individual IPSCs (gray) superimposed on an average response (red) for the indicated locations (1-4). Bottom, A scatter plot showing the mean amplitudes of laser-evoked IPSCs for the indicated locations. C, Summary of responses in pilocarpine-treated mice $(n=6-10$ cells). Top, Individual (gray) and average (red) responses for each of the sites (1-4). Bottom, Summarizes the mean IPSC amplitudes for each cell with the mean \pm SEM. ANOVA analysis with post hoc Nemenyi test showed significant differences $(p<0.05)$ within the pilocarpine groups between all locations and the hilus as well as between normal and pilocarpine groups for the LM $(p<0.025)$ and ML $(p<$ $0.05)$ locations.

tion in models of neurological disorders, the possibility of methodologically induced changes will be particularly important to consider in such studies (Miyashita et al., 2013).

A remarkable feature of O-LM and other SOM-expressing neurons that project to s. lacunosum-moleculare of CA1 is the sharp restriction of their dense axonal plexus to this layer, without extension into the immediately adjacent dentate molecular layer (Klausberger, 2009). This pattern was clearly evident in normal and control animals in the present study and has been demonstrated in previous optogenetic studies involving viral injections in s. oriens of CA1 in normal SOM-Cre mice (Royer et al., 2012). In the present study, some eYFP-labeled fibers extended from s. lacunosum-moleculare into the dentate molecular layer in normal animals following the viral injection, but this projection was small compared with the high concentration of labeled fibers in s. lacunosum-moleculare. Consistent with the anatomy, electrophysiological studies showed that negligible functional connections existed between ChR2-expressing fibers in s. lacunosum-moleculare and dentate granule cells in control animals.

The sharp restriction of labeled fibers in s. lacunosummoleculare of CA1 in normal animals emphasizes the aberrant nature of the projections into the dentate molecular layer in pilocarpine-treated mice and suggests that a strong barrier to these fibers has been breached. Likewise, the laminar-specific distribution of these axons, characteristic of many classes of GABAergic interneurons in the hippocampal formation (Halasy and Somogyi, 1993; Klausberger and Somogyi, 2008), has been disrupted.

\section{Conditions promoting aberrant SOM/GABAergic axonal sprouting}

The specific factors that promote sprouting of SOM/GABA neurons of the hippocampus into the molecular layer of the dentate gyrus are unknown. However, the deafferentation that occurs in the outer molecular layer due to the seizure-induced loss of hilar SOM-expressing neurons is likely to play a major role. Similarly, deafferentation has been considered to be a major stimulus for mossy fiber sprouting into the inner molecular layer of the dentate gyrus following loss of vulnerable mossy cells that normally innervate this region (Cavazos and Sutula, 1990; Jiao and Nadler, 2007). Receptors at the vacated synaptic sites also may serve as stimuli for synaptic reorganization as current evidence suggests that both glutamatergic and GABAergic neurons may be "replacing" synaptic connections of a comparable transmitter phenotype. Our ultrastructural findings demonstrate that the reorganized ChR2-eYFP-expressing terminals in the dentate molecular layer form distinct symmetric synapses, characteristic of normal SOM/GABAergic synapses in this region (Milner and Bacon, 1989; Leranth et al., 1990; Katona et al., 1999; Zhang et al., 2009).

Interestingly, both the depleted hilar SOM-expressing neurons and reorganized presumptive O-LM neurons of the hippocampus are dendrite-targeting GABA neurons that innervate the distal dendrites of their respective principal cells and regulate the excitability of these neurons in response to excitatory input from the entorhinal cortex, through the perforant path in the dentate gyrus or the temporoammonic path in the hippocampus (Freund and Buzsáki, 1996). Thus factors that normally lead to dendritic targeting of GABAergic innervation may contribute to appropriately positioned inhibitory input to the granule cells. However, despite the maintenance of such subcellular specificity, the functional circuitry is substantially altered.

The current findings and those of previous studies of GIN mice (Zhang et al., 2009; Buckmaster and Wen, 2011; Hunt et al., 2011) suggest that some classes of SOM-expressing neurons in the hippocampal formation have a strong propensity for axonal reorganization. Sprouting of remaining SOM-containing neu- 
rons, in both the hilus and s. oriens, is likely to contribute to the SOM reinnervation of the molecular layer following loss of hilar neurons. The type of reorganization that predominates may be determined by the relative abundance of the SOM-expressing populations that remain. However, sprouting of GABA neurons is unlikely to be limited to SOM-expressing neurons, as suggested by previous immunohistochemical findings, including increased densities of GABAergic axons expressing Type 1 cannabinoid receptors in the dentate molecular layer in a similar mouse model of epilepsy (Karlócai et al., 2011).

\section{Function of a reorganized but aberrant SOM/GABAergic circuit}

The function of the reorganized fibers in vivo is not known. Considering the functional synaptic connectivity that is demonstrated in the current study, spontaneous activity of SOMexpressing neurons in s. oriens could contribute to dendritic inhibition of granule cells during baseline conditions and thus be compensatory. Their function also could be influenced by changes in the firing patterns of the O-LM cells, as increases in firing rates and altered rhythmogenesis have been observed in O-LM neurons in CA3 in the kainate model of epilepsy (Dugladze et al., 2007). Regardless of such changes, the reorganized circuit is unlikely to operate effectively in response to perforant path stimulation or during periods of increased granule cell activity, when feedback inhibition from hilar SOM-expressing neurons is particularly important. Despite the presence of numerous inhibitory synapses in their normal positions on granule cell dendrites in the molecular layer, the granule cells are no longer establishing synaptic contacts with the neurons that provide this innervation, resulting in disruption of the normal inhibitory feedback circuit.

Nevertheless, considering the current findings of strong functional connections between GABA neurons in s. oriens and dentate granule cells in the pilocarpine-treated animals, inhibition of granule cells through the reorganized circuit appears possible. As pyramidal cells are the major excitatory input to O-LM cells (Blasco-Ibáñez and Freund, 1995), increased activity in CA1 pyramidal cells could lead to inhibition of granule cells, but with some delay and not in response to granule cell activation. One further possibility is that, if GABA were to become depolarizing in specific conditions in vivo, the GABAergic innervation from $\mathrm{s}$. oriens could contribute to increased excitability of the granule cells. Distal dendrites of granule cells, where the reorganized innervation is particularly dense, may be especially prone to such GABAergic excitatory actions (Staley et al., 1995).

The current findings demonstrate a remarkable potential for growth and synaptic reorganization of GABAergic neurons in the adult brain and raise the possibility that such alterations in GABAergic circuitry could be occurring widely throughout the hippocampus and other brain regions. Even when the normal anatomical distribution of fibers and terminals appears to be reestablished following an initial loss of GABA neurons, effectiveness of the reorganized neurons may be limited and will depend on the circuits that are formed. Indeed, aberrant GABAergic circuitry may help explain the discrepancies that are often found between an abundance of GABAergic terminals and persistent deficits in functional inhibition in epilepsy.

\section{References}

Babb TL, Kupfer WR, Pretorius JK, Crandall PH, Levesque MF (1991) Synaptic reorganization by mossy fibers in human epileptic fascia dentata. Neuroscience 42:351-363. CrossRef Medline
Bausch SB (2005) Axonal sprouting of GABAergic interneurons in temporal lobe epilepsy. Epilepsy Behav 7:390-400. CrossRef Medline

Blasco-Ibáñez JM, Freund TF (1995) Synaptic input of horizontal interneurons in stratum oriens of the hippocampal CA1 subfield: structural basis of feed-back activation. Eur J Neurosci 7:2170-2180. CrossRef Medline

Boulland JL, Ferhat L, Tallak Solbu T, Ferrand N, Chaudhry FA, StormMathisen J, Esclapez M (2007) Changes in vesicular transporters for gamma-aminobutyric acid and glutamate reveal vulnerability and reorganization of hippocampal neurons following pilocarpine-induced seizures. J Comp Neurol 503:466-485. CrossRef Medline

Buckmaster PS, Dudek FE (1997) Neuron loss, granule cell axon reorganization, and functional changes in the dentate gyrus of epileptic kainatetreated rats. J Comp Neurol 385:385-404. CrossRef Medline

Buckmaster PS, Wen X (2011) Rapamycin suppresses axon sprouting by somatostatin interneurons in a mouse model of temporal lobe epilepsy. Epilepsia 52:2057-2064. CrossRef Medline

Cavalheiro EA, Fernandes MJ, Turski L, Naffah-Mazzacoratti MG (1994) Spontaneous recurrent seizures in rats: amino acid and monoamine determination in the hippocampus. Epilepsia 35:1-11. CrossRef Medline

Cavazos JE, Sutula TP (1990) Progressive neuronal loss induced by kindling: a possible mechanism for mossy fiber synaptic reorganization and hippocampal sclerosis. Brain Res 527:1-6. CrossRef Medline

Davenport CJ, Brown WJ, Babb TL (1990) Sprouting of GABAergic and mossy fiber axons in dentate gyrus following intrahippocampal kainate in the rat. Exp Neurol 109:180-190. CrossRef Medline

Dinocourt C, Petanjek Z, Freund TF, Ben-Ari Y, Esclapez M (2003) Loss of interneurons innervating pyramidal cell dendrites and axon initial segments in the CA1 region of the hippocampus following pilocarpineinduced seizures. J Comp Neurol 459:407-425. CrossRef Medline

Dugladze T, Vida I, Tort AB, Gross A, Otahal J, Heinemann U, Kopell NJ, Gloveli T (2007) Impaired hippocampal rhythmogenesis in a mouse model of mesial temporal lobe epilepsy. Proc Natl Acad Sci U S A 104: 17530-17535. CrossRef Medline

Elfant D, Pál BZ, Emptage N, Capogna M (2008) Specific inhibitory synapses shift the balance from feedforward to feedback inhibition of hippocampal CA1 pyramidal cells. Eur J Neurosci 27:104-113. Medline

Esclapez M, Houser CR (1999) Up-regulation of GAD65 and GAD67 in remaining hippocampal GABA neurons in a model of temporal lobe epilepsy. J Comp Neurol 412:488-505. CrossRef Medline

Esclapez M, Hirsch JC, Ben-Ari Y, Bernard C (1999) Newly formed excitatory pathways provide a substrate for hyperexcitability in experimental temporal lobe epilepsy. J Comp Neurol 408:449-460. CrossRef Medline

Freund TF, Buzsáki G (1996) Interneurons of the hippocampus. Hippocampus 6:347-470. Medline

Gulyás AI, Hájos N, Katona I, Freund TF (2003) Interneurons are the local targets of hippocampal inhibitory cells which project to the medial septum. Eur J Neurosci 17:1861-1872. CrossRef Medline

Halasy K, Somogyi P (1993) Subdivision in the multiple GABAergic innervation of granule cells in the dentate gyrus of the rat hippocampus. Eur J Neurosci 5:411-429. CrossRef Medline

Halasy K, Buhl EH, Lörinczi Z, Tamás G, Somogyi P (1996) Synaptic target selectivity and input of GABAergic basket and bistratified interneurons in the $\mathrm{CA} 1$ area of the rat hippocampus. Hippocampus 6:306-329. CrossRef Medline

Houser CR, Esclapez M (1996) Vulnerability and plasticity of the GABA system in the pilocarpine model of spontaneous recurrent seizures. Epilepsy Res 26:207-218. CrossRef Medline

Houser CR, Miyashiro JE, Swartz BE, Walsh GO, Rich JR, Delgado-Escueta AV (1990) Altered patterns of dynorphin immunoreactivity suggest mossy fiber reorganization in human hippocampal epilepsy. J Neurosci 10:267-282. Medline

Houser CR, Huang CS, Peng Z (2004) Axonal sprouting of somatostatin neurons in the molecular layer of the dentate gyrus in a mouse model of temporal lobe epilepsy. Soc Neurosci Abstr 30:567.5.

Houser CR, Huang CS, Peng Z (2008) Dynamic seizure-related changes in extracellular signal-regulated kinase activation in a mouse model of temporal lobe epilepsy. Neuroscience 156:222-237. CrossRef Medline

Hunt RF, Scheff SW, Smith BN (2011) Synaptic reorganization of inhibitory hilar interneuron circuitry after traumatic brain injury in mice. J Neurosci 31:6880-6890. CrossRef Medline

Jiao Y, Nadler JV (2007) Stereological analysis of GluR2-immunoreactive hilar neurons in the pilocarpine model of temporal lobe epilepsy: corre- 
lation of cell loss with mossy fiber sprouting. Exp Neurol 205:569-582. CrossRef Medline

Jinno S, Klausberger T, Marton LF, Dalezios Y, Roberts JD, Fuentealba P, Bushong EA, Henze D, Buzsáki G, Somogyi P (2007) Neuronal diversity in GABAergic long-range projections from the hippocampus. J Neurosci 27:8790-8804. CrossRef Medline

Karlócai MR, Tóth K, Watanabe M, Ledent C, Juhász G, Freund TF, Maglóczky Z (2011) Redistribution of CB1 cannabinoid receptors in the acute and chronic phases of pilocarpine-induced epilepsy. PLoS One 6:e27196. CrossRef Medline

Katona I, Acsády L, Freund TF (1999) Postsynaptic targets of somatostatinimmunoreactive interneurons in the rat hippocampus. Neuroscience 88: 37-55. CrossRef Medline

Klausberger T (2009) GABAergic interneurons targeting dendrites of pyramidal cells in the CAl area of the hippocampus. Eur J Neurosci 30:947-957. CrossRef Medline

Klausberger T, Somogyi P (2008) Neuronal diversity and temporal dynamics: the unity of hippocampal circuit operations. Science 321:53-57. CrossRef Medline

Leão RN, Mikulovic S, Leão KE, Munguba H, Gezelius H, Enjin A, Patra K, Eriksson A, Loew LM, Tort AB, Kullander K (2012) OLM interneurons differentially modulate $\mathrm{CA} 3$ and entorhinal inputs to hippocampal CA1 neurons. Nat Neurosci 15:1524-1530. CrossRef Medline

Leranth C, Malcolm AJ, Frotscher M (1990) Afferent and efferent synaptic connections of somatostatin-immunoreactive neurons in the rat fascia dentata. J Comp Neurol 295:111-122. CrossRef Medline

Lorente de Nó R (1934) Studies on the structure of the cerebral cortex. II. Continuation of the study of the ammonic system. J Psychol Neurol 46:113-177.

Lovett-Barron M, Turi GF, Kaifosh P, Lee PH, Bolze F, Sun XH, Nicoud JF, Zemelman BV, Sternson SM, Losonczy A (2012) Regulation of neuronal input transformations by tunable dendritic inhibition. Nat Neurosci 15: 423-430, S1-S3. CrossRef Medline

Lutz C, Otis TS, DeSars V, Charpak S, DiGregorio DA, Emiliani V (2008) Holographic photolysis of caged neurotransmitters. Nat Methods 5:821827. CrossRef Medline

Ma Y, Hu H, Berrebi AS, Mathers PH, Agmon A (2006) Distinct subtypes of somatostatin-containing neocortical interneurons revealed in transgenic mice. J Neurosci 26:5069-5082. CrossRef Medline

Mathern GW, Babb TL, Pretorius JK, Leite JP (1995) Reactive synaptogenesis and neuron densities for neuropeptide $\mathrm{Y}$, somatostatin, and glutamate decarboxylase immunoreactivity in the epileptogenic human fascia dentata. J Neurosci 15:3990-4004. Medline

McBain CJ, DiChiara TJ, Kauer JA (1994) Activation of metabotropic glutamate receptors differentially affects two classes of hippocampal interneurons and potentiates excitatory synaptic transmission. J Neurosci 14:4433-4445. Medline

Meier CL, Dudek FE (1996) Spontaneous and stimulation-induced synchronized burst afterdischarges in the isolated CAl of kainate-treated rats. J Neurophysiol 76:2231-2239. Medline

MilnerTA, Bacon CE (1989) Ultrastructurallocalization of somatostatinlike immunoreactivity in the rat dentate gyrus. J Comp Neurol 290: 544-560. CrossRef Medline

Miyashita T, Shao YR, Chung J, Pourzia O, Feldman DE (2013) Long-term channelrhodopsin-2 (ChR2) expression can induce abnormal axonal morphology and targeting in cerebral cortex. Front Neural Circuits 7:8. Medline

Mody I, Otis TS, Bragin A, Hsu M, Buzsáki G (1995) GABAergic inhibition of granule cells and hilar neuronal synchrony following ischemia-induced hilar neuronal loss. Neuroscience 69:139-150. CrossRef Medline

Morin F, Beaulieu C, Lacaille JC (1998) Selective loss of GABA neurons in area $\mathrm{CA} 1$ of the rat hippocampus after intraventricular kainate. Epilepsy Res 32:363-369. CrossRef Medline
Oliva AA Jr, Jiang M, Lam T, Smith KL, Swann JW (2000) Novel hippocampal interneuronal subtypes identified using transgenic mice that express green fluorescent protein in GABAergic interneurons. J Neurosci 20:3354-3368. Medline

Paxinos G, Franklin KBJ (2001) The mouse brain in stereotaxic coordinates. San Diego: Academic.

Peng Z, Houser CR (2005) Temporal patterns of fos expression in the dentate gyrus after spontaneous seizures in a mouse model of temporal lobe epilepsy. J Neurosci 25:7210-7220. CrossRef Medline

Peng Z, Huang CS, Cetina Y, Zhang N, Houser CR (2013) A reorganized GABAergic circuit in a model of epilepsy: evidence from Cre-dependent labeling in a somatostatin-Cre mouse. Epilepsy Curr 13 [Suppl 1]:331.

Perez Y, Morin F, Beaulieu C, Lacaille JC (1996) Axonal sprouting of CA1 pyramidal cells in hyperexcitable hippocampal slices of kainate-treated rats. Eur J Neurosci 8:736-748. CrossRef Medline

Royer S, Zemelman BV, Losonczy A, Kim J, Chance F, Magee JC, Buzsáki G (2012) Control of timing, rate and bursts of hippocampal place cells by dendritic and somatic inhibition. Nat Neurosci 15:769-775. CrossRef Medline

Santhakumar V, Hanchar HJ, Wallner M, Olsen RW, Otis TS (2006) Contributions of the $\mathrm{GABA}_{\mathrm{A}}$ receptor $\alpha 6$ subunit to phasic and tonic inhibition revealed by a naturally occurring polymorphism in the $\alpha 6$ gene. J Neurosci 26:3357-3364. CrossRef Medline

Sik A, Penttonen M, Ylinen A, Buzsáki G (1995) Hippocampal CA1 interneurons: an in vivo intracellular labeling study. J Neurosci 15:66516665. Medline

Smith BN, Dudek FE (2001) Short- and long-term changes in CA1 network excitability after kainate treatment in rats. J Neurophysiol 85:1-9. Medline

Somogyi P, Klausberger T (2005) Defined types of cortical interneurone structure space and spike timing in the hippocampus. J Physiol 562:9-26. Medline

Staley KJ, Soldo BL, Proctor WR (1995) Ionic mechanisms of neuronal excitation by inhibitory $\mathrm{GABA}_{\mathrm{A}}$ receptors. Science 269:977-981. CrossRef Medline

Sutula T, Cascino G, Cavazos J, Parada I, Ramirez L (1989) Mossy fiber synaptic reorganization in the epileptic human temporal lobe. Ann Neurol 26:321-330. CrossRef Medline

Tauck DL, Nadler JV (1985) Evidence of functional mossy fiber sprouting in hippocampal formation of kainic acid-treated rats. J Neurosci 5:1016-1022. Medline

Thind KK, Yamawaki R, Phanwar I, Zhang G, Wen X, Buckmaster PS (2010) Initial loss but later excess of GABAergic synapses with dentate granule cells in a rat model of temporal lobe epilepsy. J Comp Neurol 518:647-667. CrossRef Medline

Vaziri A, Emiliani V (2012) Reshaping the optical dimension in optogenetics. Curr Opin Neurobiol 22:128-137. CrossRef Medline

Wyeth MS, Zhang N, Mody I, Houser CR (2010) Selective reduction of cholecystokinin-positive basket cell innervation in a model of temporal lobe epilepsy. J Neurosci 30:8993-9006. CrossRef Medline

Zhang F, Gradinaru V, Adamantidis AR, Durand R, Airan RD, de Lecea L, Deisseroth K (2010) Optogenetic interrogation of neural circuits: technology for probing mammalian brain structures. Nat Protoc 5:439-456. CrossRef Medline

Zhang N, Houser CR (1999) Ultrastructural localization of dynorphin in the dentate gyrus in human temporal lobe epilepsy: a study of reorganized mossy fiber synapses. J Comp Neurol 405:472-490. CrossRef Medline

Zhang W, Yamawaki R, Wen X, Uhl J, Diaz J, Prince DA, Buckmaster PS (2009) Surviving hilar somatostatin interneurons enlarge, sprout axons, and form new synapses with granule cells in a mouse model of temporal lobe epilepsy. J Neurosci 29:14247-14256. CrossRef Medline 